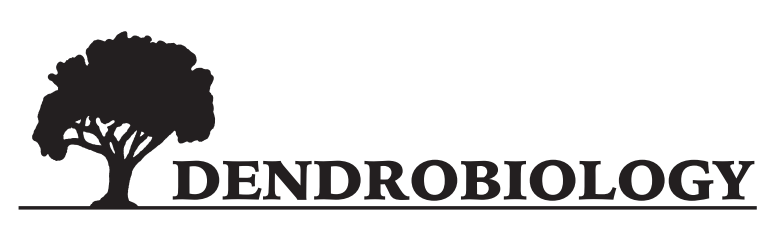

2017, vol. 77, 119-137

http://dx.doi.org/10.12657/denbio.077.010

\author{
Ivo Králiček, Zdeněk Vacek, Stanislav Vacek, Jiř́ Remeš*, \\ Daniel Bulušek, Jan Král, Igor Štefančík, Tereza Putalová
}

\title{
Dynamics and structure of mountain autochthonous spruce-beech forests: impact of hilltop phenomenon, air pollutants and climate
}

\author{
Received: 3 February 2017; Accepted: 7 February 2017
}

\begin{abstract}
Mountain forests are strongly influenced by the extreme climate, short growing season and stress from environmental pollution and lower fertility of soils. The paper analyses the effect of the environment (climate and air pollutants) on the structure, production and dynamics of autochthonous spruce-beech forest stands in protected areas in the summit parts of the Orlické hory Mts., Czech Republic. The spatial pattern of tree layer was random in lower parts below the summit and aggregated under the hilltop phenomenon on an extreme edaphic site, such as aggregated horizontal structure of natural regeneration. In most cases, the relationship between the spatial pattern of tree layer and natural regeneration was significantly negative $(\alpha=0.05)$ at a smaller distance (from stem to $0.6-6.1 \mathrm{~m}$ ) except stands under the strong hilltop phenomenon (positive effect to $2.1 \mathrm{~m}$ ). The stand density ranged from 440 to 760 trees ha $\mathrm{h}^{-1}$ and the number of natural regeneration was 4 584-6 360 recruits ha $\mathrm{h}^{-1}$. Dominant height decreased with increasing influence of hilltop phenomenon $(\mathrm{P}<0.001)$. The volume of live trees was $239-536 \mathrm{~m}^{3} \mathrm{ha}^{-1}$. The radial growth of dominant European beech (Fagus sylvatica L.) indicated a relatively balanced long-term trend of tree-ring width in 1900-2014, but diameter increment of admixed Norway spruce (Picea abies /L./ Karst.) after 1978 significantly decreased $(\mathrm{P}<0.001)$ and since 1998 radial increment in spruce distinctly increased. Radial growth of spruce was significantly negatively correlated with mean $\mathrm{SO}_{2}$ and $\mathrm{NO}_{\mathrm{x}}$ concentrations, especially in April $(\mathrm{P}<0.001)$, but there was no effect on radial growth of beech. Air pollution had a significantly higher negative effect on radial growth of spruce on the hilltop compared to the lower part of the hill. The correlation between radial increment and temperature was stronger than in precipitation for both species in mountain areas compared to lowlands. The hilltop phenomenon significantly influenced the structure of spruce-beech mountain forests. The lowest dynamics was observed in stands in middle slope parts compared to summit parts of the hill.
\end{abstract}

Keywords: natural forests, biodiversity, stress factors, Fagus sylvatica, Picea abies, Orlické hory Mts.

Addresses: I. Králíček, University of Hradec Králové, Faculty of Science, Rokitanského 62, 50003 Hradec Králové, Czech Republic

Z. Vacek, S. Vacek, J. Remeš, D. Bulušek, J. Král, T. Putalová, Czech University of Life Sciences in Prague, Faculty of Forestry and Wood Sciences, Kamýcká 129, 16521 Prague 6 - Suchdol, Czech Republic, e-mail: remesj@email.cz I. Štefančík, National Forest Centre, Forest Research Institute, T. G. Masaryka 22, 96092 Zvolen, Slovak Republic 


\section{Introduction}

Almost all native forests in Europe have been influenced by economic activity and virgin forests currently account there for less than $1 \%$ (Vanbergen et al., 2005). The situation is similar in the Czech Republic $(1.1 \%)$, and also in the area of interest in the Orlické hory Mts. (0.8\%) (cf. Vacek et al., 2012). This percentage is higher in Slovakia, where according to the national inventory natural forests range around $5.0 \%$ (Šmelko et al., 2008). However, it is much less than e.g. on the western coast of the USA, where they account for $13 \%$, or in Canada, where they account even for 40-52\% (Heywood \& Watson, 1995; Parviainen et al., 2000). For this reason species diversity and ecological stability in these forests should be paid higher attention (cf. Scherer-Lorenzen et al., 2005). Ministerial conferences on forest conservation in Europe have also declared the need of arresting the loss of biological diversity and supporting sustainable management (Parviainen et al., 2007). Thanks to their long history, natural forests are an ideal subject for research on age, spatial structure and biodiversity (Commarmot et al., 2013; Nagel et al., 2013). They are also considered as reference or model objects for sustainable forest management (Angermeier, 2000; Wesolowski, 2005; Holeksa et al., 2009) and higher stand diversity (at the level of structural and tree species diversity) than commercial forests on comparable sites (Siitonen, 2001; Okland et al., 2003; Král et al., 2010).

The study of mixed stands is generally of great importance for the evaluation of their structure, productivity, ecological stability and dynamics compared to pure stands (cf. Bolte et al., 2010; Pretzsch et al., 2010; Pretzsch \& Schütze, 2014). It also provides valuable information about how the given mixed stand changes parameters of tree crowns (Dieler \& Pretzsch, 2013), stem growth (Webster \& Lorimer, 2003) and root growth and their relations (Schmid \& Kazda, 2001) in comparison with pure stands. Research of natural mixed forests is important for the formulation of close-to-nature management of forest ecosystems because commercial forests currently suffer from frequent structural disturbances, mainly homogeneous stands with minimum structural differentiation (cf. Commarmot et al., 2005). Thorough systematic silvicultural treatment enhances the stability of stands and safety of production and thereby reduces the level of disturbance (cf. Slodičák \& Novák, 2006; Štefančík \& Bošela, 2014). Natural disturbances at comparable habitats usually occur less frequently in closeto-nature forests compared to managed forests (cf. Yamamoto, 2000; Angelstam \& Kuuluvainen, 2004). In managed forests a higher level of disturbances can also be assumed in relation to climate change (Fuhrer et al., 2006; Hanewinkel \& Peyron, 2014).
For this reason our research was aimed at natural forests in the Orlické hory Mts., where European beech (Fagus sylvatica L.) was a significant tree species in the natural species composition (cf. Vacek et al., 2014) because it accounted for $33.8 \%$ in the natural composition (cf. Vacek et al., 2003) and currently its share is only $5.5 \%$ (Vacek et al., 2012).

Besides other factors, the growth of a tree is strongly influenced by the climate and air pollution. For several decades many research studies have been aimed at acquiring better knowledge of the relationship between tree growth and climatic conditions (Spiecker, 1999; Lindner et al., 2014; Bílek et al., 2015; Rohner et al., 2016) and air pollution (Hauck et al., 2012; Král et al., 2015; Vacek et al., 2015a). Moreover mountain forests, especially summit parts under the hilltop phenomenon, are highly sensitive ecosystems, exposed to a significant burden from multiple stressors (Buttoud, 2000; Bridgman et al., 2002), such as emission impacts $\left(\mathrm{SO}_{2}, \mathrm{O}_{3}\right.$, acid deposition), extreme climate (strong drought, low temperatures, high winds), and adverse soil conditions (acidic soils) (Kärenlampi \& Skärby, 1996; Hruška \& Ciencala, 2003; Gallo et al., 2014; Vacek et al., 2015a). On the studied site, the onset of a strong air pollution stress in the mountains in the late seventies (after the Chvaletice power station was put into operation in 1977) highly stimulated the dynamics of forest ecosystem destruction as a result of the synergistic action of emissions, climatic extremes and biotic pests (Vacek et al., 2003; Vacek et al., 2015a). These factors operate mostly synergistically in the mountain forests and it is usually difficult to precisely separate them (Tranquillini, 1979).

The above-mentioned hilltop phenomenon is primarily determined by topography (Jeník, 1961). This phenomenon is characterized by any abiotic factor which implies necessary adaptation of local vegetation to poor conditions (Tranquillini, 1979). The expression of hilltop phenomenon can occur in three fields - climate (temperature, solar radiation, wind, ice etc.), changes of soil (acidification, degradation, erosion, etc.) and vegetation (local diversity, change in the shape of trees, shift of timberline, etc.) (Kučera, 1997; Holtmeier, 2003). This phenomenon causes reduced growth of trees, lower stand stocking, aggregated spatial pattern of the tree layer and lower canopy cover compared to forests at lower altitudes and in valleys (Bulušek et al., 2016).

Research on physiological aspects of tree growth and stand structure has been gaining still greater importance in connection with climate change (Orwig \& Abrams, 1997), also from the aspect of climate reconstructions (Neukomm et al., 2014) and quantification of the expected tree growth under various climate scenarios (Fontes et al., 2010). These scenarios are highly important for the formulation of 
adaptation strategies of sustainable or close-to-nature forest management during the oncoming global climate changes (Lindner et al., 2014).

In the centre of its natural habitat the beech is a very successful tree species, especially in relation to global climate changes (Leuschner et al., 2006; Bolte et al., 2010). On the northern edge of its habitat in southern Sweden the average annual temperature has increased by ca. $1^{\circ} \mathrm{C}$ in the last 100 years and it is assumed to rise by $2-6^{\circ} \mathrm{C}$ by the end of this century (Christensen \& Christensen, 2007). The extension of the growing season, decrease in precipitation amount by up to $40 \%$ and vulnerability to windthrows may favour European beech to Norway spruce (Picea abies /L./ Karst.) (Schlyter et al., 2006; Christensen et al., 2007; Bolte et al., 2009). Besides warming, drought increase and more frequent wind storms the spruce will be increasingly accompanied by other biological threats due to changes in pathogenic regimes (Jönsson et al., 2007; Dobbertin \& De Vries, 2008). Climate changes can have a great influence on vitality, growth, reproduction and disturbances (Bolte et al., 2010).

The aims of this study were 1) detailed evaluation of structure, production and dynamics of unique fragments of autochthonous mountain spruce-beech forests under different influences of hilltop phenomenon, 2) determination of the effect of air pollutants $\left(\mathrm{SO}_{2}\right.$ and $\mathrm{NO}_{\mathrm{X}}$ concentrations) and climate (temperature and precipitations) on the radial growth of European beech and Norway spruce and 3) description of interactions between habitat conditions, climate factors, production parameters, structural diversity and model development of these stands.

\section{Material and Methods}

\section{Description of study area}

Permanent research plots (RPR) are situated in Bukačka National Nature Reserve (50.7 ha), Sedloňovký vrch Nature Reserve (84.5 ha), Pod Vrchmezím Nature Reserve (16.0 ha) and Komáŕí vrch Nature Reserve (12.7 ha) in summit parts of the Orlické hory Mts. Protected Landscape Area (PLA) and they belong to Natural Forest Area 22 - Orlické hory Mts. (Fig. 1). The protection of these localities was declared in 1954-1973 and the studied plots have been left to spontaneous development. Historically, major interventions in the natural composition of forests in the Orlické hory Mts. were carried out in 1574-1703,

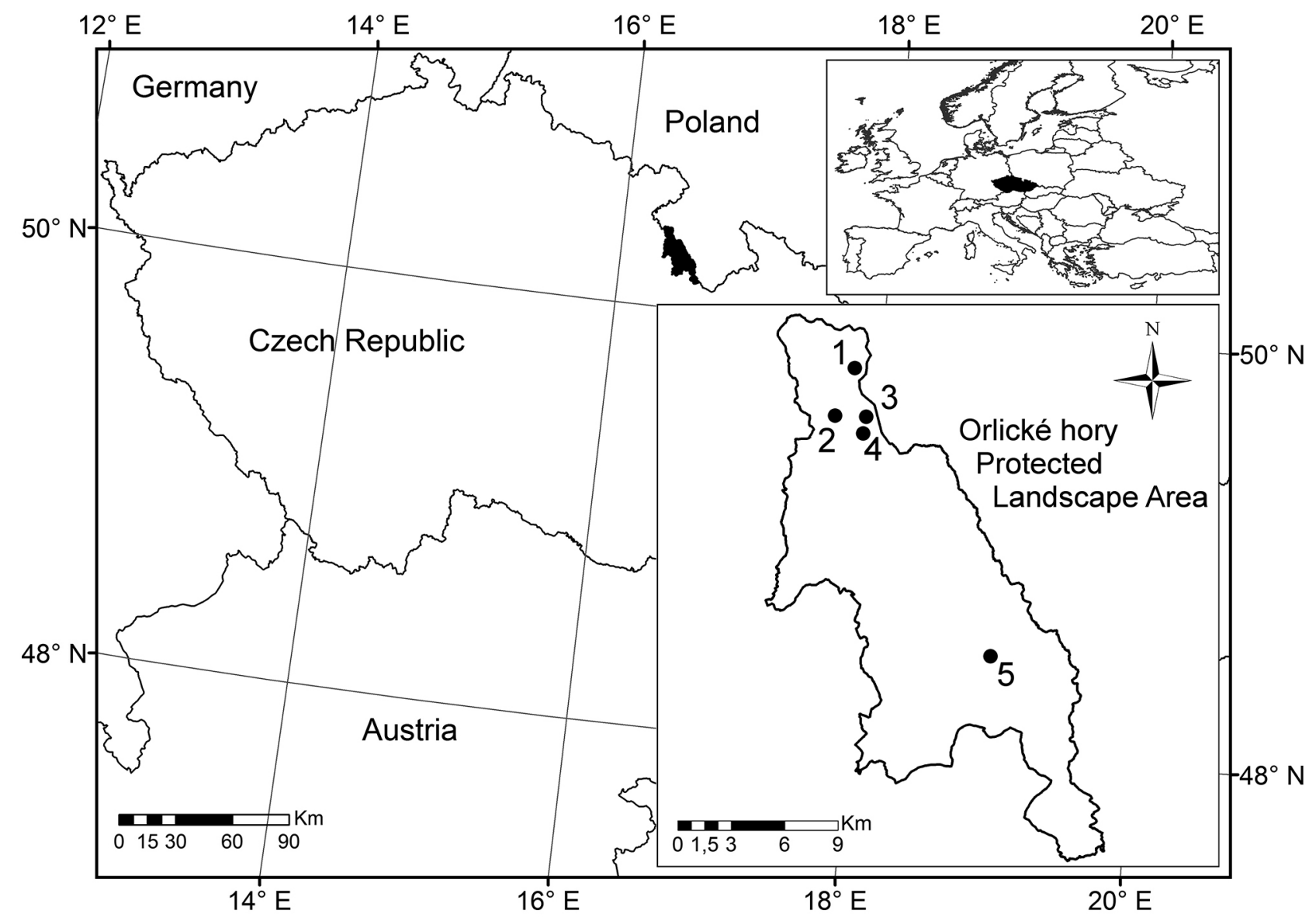

Fig. 1. Localization of permanent research plots in the Orlické hory Mts. Protected Landscape Area 
Table 1. Basic site characteristics of permanent research plots

\begin{tabular}{|c|c|c|c|c|c|c|c|c|c|c|c|c|}
\hline Plot name & GPS & $\begin{array}{l}\text { Alti- } \\
\text { tude } \\
\text { (m) }\end{array}$ & $\begin{array}{l}\text { Temper- } \\
\text { ature in } \\
\mathrm{GS}^{1}\left({ }^{\circ} \mathrm{C}\right)\end{array}$ & $\begin{array}{c}\text { Rainfall } \\
\text { in GS } \\
(\mathrm{mm})\end{array}$ & $\begin{array}{l}\text { Ex- } \\
\text { po- } \\
\text { sure }\end{array}$ & $\begin{array}{c}\text { Slope } \\
\left({ }^{\circ}\right)\end{array}$ & $\begin{array}{l}\text { Forest } \\
\text { site } \\
\text { type }^{2}\end{array}$ & Soil type & $\begin{array}{c}\text { Soil } \\
\mathrm{pH} \\
\mathrm{H}_{2} \mathrm{O}^{3}\end{array}$ & $\begin{array}{c}\text { Content } \\
\mathrm{C}: \mathrm{N}^{3} \\
(\%)\end{array}$ & $\begin{array}{c}\text { Base sat- } \\
\text { uration } \\
\mathrm{V}^{3}(\%)\end{array}$ & $\begin{array}{l}\text { Hilltop } \\
\text { phenom- } \\
\text { enon }^{4}\end{array}$ \\
\hline $\begin{array}{l}\text { Pod Vrch- } \\
\text { mezím }\end{array}$ & $\begin{array}{l}50^{\circ} 21^{\prime} 30.3^{\prime \prime} \mathrm{N} \\
16^{\circ} 21^{\prime} 37.5^{\prime \prime} \mathrm{E}\end{array}$ & 905 & 10.7 & 620 & NW & 21 & $6 \mathrm{~K}$ & $\begin{array}{l}\text { modal Cam- } \\
\text { bisol }\end{array}$ & 4.62 & 11.86 & 15.32 & weak \\
\hline $\begin{array}{l}\text { Sedloňovský } \\
\text { vrch }\end{array}$ & $\begin{array}{l}50^{\circ} 20^{\prime} 21.5^{\prime \prime} \mathrm{N} \\
16^{\circ} 21^{\prime} 13.4^{\prime \prime} \mathrm{E}\end{array}$ & 990 & 9.8 & 650 & W & 16 & $6 \mathrm{~K}$ & $\begin{array}{c}\text { modal } \\
\text { Cambisol }\end{array}$ & 3.88 & 18.44 & 13.48 & strong \\
\hline Bukačka 1 & $\begin{array}{l}50^{\circ} 20^{\prime} 08.6^{\prime \prime} \mathrm{N} \\
16^{\circ} 22^{\prime} 35.3^{\prime \prime} \mathrm{E}\end{array}$ & 990 & 9.2 & 670 & W & 5 & $7 \mathrm{~K}$ & $\begin{array}{c}\text { modal } \\
\text { Cryptopodzol }\end{array}$ & 3.44 & 21.55 & 12.10 & strong \\
\hline Bukačka 2 & $\begin{array}{l}50^{\circ} 19^{\prime} 56.3^{\prime \prime} \mathrm{N} \\
16^{\circ} 22^{\prime} 35.3^{\prime \prime} \mathrm{E}\end{array}$ & 940 & 9.8 & 670 & W & 12 & $6 S$ & $\begin{array}{l}\text { modal } \\
\text { Cambisol }\end{array}$ & 3.50 & 11.89 & 19.00 & medium \\
\hline Komáŕí vrch & $\begin{array}{l}50^{\circ} 13^{\prime} 51.8^{\prime \prime} \mathrm{N} \\
16^{\circ} 22^{\prime} 31.4^{\prime \prime} \mathrm{E}\end{array}$ & 965 & 10.0 & 640 & SE & 10 & $6 \mathrm{~K}$ & $\begin{array}{l}\text { Cambisol } \\
\text { Leptosol }\end{array}$ & 3.61 & 8.86 & 10.90 & medium \\
\hline
\end{tabular}

Notes: ${ }^{1} \mathrm{GS}$ - growing season; ${ }^{2}$ Forest site type: $6 \mathrm{~K}$ - acidic spruce-beech stand, $6 \mathrm{~S}$ - fresh spruce-beech stand, $7 \mathrm{~K}$ - acidic beech-spruce stand; ${ }^{3}$ value in Ah upper soil humus horizon, ${ }^{4}$ influence of hilltop phenomenon: strong (summit parts of the hill), medium (parts of the hill just below the peak), weak (middle slope parts of the hill).

when most of the forests were harvested for Kutná hora mines (Vacek et al., 2003). The studied stands are situated at localities hardly accessible by any means of transport, and therefore these forests were preserved. In the 19th century roving cuts were conducted in the studied areas. In the first half of the 20th century individual tree selection was realized on Bukačka PRP 4 and Komáří vrch PRP 5 (Vacek et al., 2012).

Average annual temperature is around $4.8^{\circ} \mathrm{C}$ and annual precipitation amount is ca. $1200 \mathrm{~mm}$. The length of the growing season (GS) ranges around 105 days. Average annual concentrations of $\mathrm{SO}_{2}$ at the Šerlich Station have been around $10 \mu \mathrm{g} \mathrm{m}^{-3}$ in the last years, in $\mathrm{NO}_{\mathrm{x}}$ it is $15 \mu \mathrm{g} \mathrm{m}^{-3}$ and average maximum 8-hour annual concentrations of $\mathrm{O}_{3}$ are around $80 \mu \mathrm{g} \mathrm{m}^{-3}$. In the time of air-pollution load in the $80 \mathrm{~s}$ of the $20^{\text {th }}$ century these values were much higher, especially those of $\mathrm{SO}_{2}$ were several times higher (cf. Vacek et al., 2015a).

The bedrock is mostly composed of crystalline schists, gneisses and mica schists. Modal Cambisols and Cryptopodzols are prevailing soil types. Soils are strongly acidic, only on PRP 3 strongly acidic and on PRP 1 medium acidic (Tab. 1). The C: $\mathrm{N}$ ratio indicates that mineralization predominates over immobilization on most PRP, only on PRP 3 immobilization prevails over mineralization (Vacek et al., 2014; Podrázský \& Vacek, 1996). The species composition of the studied reserves mainly consists of Norway spruce (Picea abies /L./ Karst., 64-90\%) and European beech (Fagus sylvatica L., 10-34\%). The proportion of rowan (Sorbus aucuparia L.), sycamore maple (Acer pseudoplatanus L.) and silver fir (Abies alba Mill.) is below $1 \%$. The herb layer is composed of the species of spruce-fir-beech stands belonging mostly to the alliance Luzulo-Fagion (Vacek et al., 2014).

Basic characteristics of the studied PRP that are situated in comparable habitat and stand conditions with dominant European beech and admixed Norway spruce in summit parts of the mountains with the pronounced hilltop phenomenon are documented in
Tab. 1. In terms of forest dynamics, studied stands are in the final optimum stage of the climax forest (Korpel, 1995).

\section{Data collection}

The FieldMap technology (IFER-Monitoring and Mapping Solutions Ltd) was used for the establishment of five PRP of $50 \times 50 \mathrm{~m}$ in size ( $0.25 \mathrm{ha})$. Positions, crown projection areas, breast-height diameters (dbh), tree heights and heights of the live crown base were measured in the tree layer (from $\mathrm{dbh} \geq 4 \mathrm{~cm}$ ) for determine stand structure and diversity. In dead wood (diameter at the smaller end $\geq$ $7 \mathrm{~cm}$, length $\geq 1 \mathrm{~m}$ ) determined characteristics were position, tree species and degree of decomposition [five-point scale according to Spetich et al. (2002); 1 - trunk untouched by decomposition, 5 - final phase of decomposition]. In recruits $(\mathrm{h} \geq 10 \mathrm{~cm}, \mathrm{dbh}<4$ $\mathrm{cm})$ position, height and crown width were measured for the particular tree species.

Data for the analysis or relations among dynamics of radial growth and climatic factors and air pollutants were acquired by taking the increment cores at a height of $1.3 \mathrm{~m}$ with a Pressler borer from 30 live dominant and codominant (tree classes 1-3 according to Kraft, 1884) beech and spruce trees with well-developed crowns on the particular PRP. Treering widths were measured to the nearest $0.01 \mathrm{~mm}$ with an Olympus stereo microscope on a LINTAB measurement table and recorded by the TSAPWIN software (RESISTOGRAPH).

Air pollutants and climate data from meteorological stations were used to determine impact of stress factors on the diameter increment of trees. For the analysis of air-pollution situation in the Orlické hory Mts. area according to concentrations of $\mathrm{SO}_{2}$ (19712014) and $\mathrm{NO}_{\mathrm{x}}$ (1992-2012) data available from the Desná-Souš station (772 m a.s.l.; GPS $50^{\circ} 47^{\prime} 21 " \mathrm{~N}$, $15^{\circ} 19^{\prime} 11 " \mathrm{E}$; average distance from PRP $85 \mathrm{~km}$ ) were used. Both average and maximum values of 
concentrations in $\mu \mathrm{g} \mathrm{m}^{3}$ and their $95 \%$ quantiles were used for evaluation. Climate behaviour with respect to temperature and precipitation conditions was evaluated on the basis of data from the Deštné meteorological station in the Orlické hory Mts. (656 m a.s.l.; GPS $50^{\circ} 18^{\prime} 24^{\prime \prime} \mathrm{N}, 16^{\circ} 21^{\prime} 07 " \mathrm{E}$; average distance from PRP $6 \mathrm{~km}$ ) in the period 1963-2014.

\section{Data analysis}

Based on the measured dendrometric data stand characteristics including stand volume (Petráš \& Pajtík, 1991), stocking (Reineke, 1933) and canopy density (crown closure and crown projection area) were computed for the tree layer $(\mathrm{dbh} \geq 4 \mathrm{~cm})$. Height curves were constructed using the Näslund height-diameter function (Näslund, 1936).

To evaluate structural diversity of the stand the following indices were determined: Arten-profil index (Pretzsch, 2006), diameter and height differentiation index (Füldner, 1995) and stand diversity index (Jaehne \& Dohrenbusch, 1997). Production and structure analysis were calculated to comparison of PRP under different influence of hilltop phenomenon and sites parameters.

In all individuals of natural regeneration and tree layer the spatial pattern was evaluated using Pielou-Mountford index (Mountford, 1961), Clark-Evans index (Clark \& Evans, 1954) and the L-function (Ripley, 1981). Tab. 2 shows the criteria of structural indices. The PointPro 2 programme (Zahradnik $\&$ Pus) was used for the computation of horizontal structure. The test of significance of deviations from the values expected for the random pattern of points was done by Monte Carlo simulations (999 randomly generated points). A relationship between the spatial pattern of tree layer and natural regeneration was calculated using R 3.1. software (c) 2014 The R Foundation) by the pair cross-correlation function (Stoyan \& Stoyan, 1992). Situational maps were created in the ArcGIS 10.0 programme (Esri).

Prediction of the stand development was carried out using SIBYLA 5 growth simulator (Fabrika, Pretzsch \& Durský). The modelling of spontaneous development of stands was realized to 2054 and for a higher statistical accuracy of prediction the simulation was repeated $25 \times$ (Ambrož et al., 2015). The characteristics of individual trees, soil moisture, nutrients and climate data were used as input data.

Tree-ring increment series were individually cross-dated (removal of errors connected with the occurrence of missing tree rings) using statistical t-tests in the PAST application (Hammer \& Harper) and consequently they were subjected to a visual inspection according to Yamaguchi (1991). If a missing tree ring was revealed, a tree ring of $0.01 \mathrm{~mm}$ in width was inserted in its place. Individual curves from PRP were detrended in a standard way and an average tree-ring series was created from them in the ARSTAN software (Laboratory of Tree-Ring Research). The 100year spline was applied (Grissino-Mayer et al., 1992). The analysis of negative pointer years was done according to Schweingruber et al. (1990). The pointer year was tested for each tree as an extremely narrow tree ring that does not reach $40 \%$ of the average of increments from 4 preceding years. The occurrence of a negative year was proved if such a strong increment reduction occurred at least in $20 \%$ of the trees on the plot. Average tree ring series from PRP were correlated with climate data (monthly amount of precipitation and mean temperatures) and air-pollution data (concentrations of $\mathrm{SO}_{2}$ and $\mathrm{NO}_{\mathrm{x}}$ ). The DendroClim software (DendroLab) was used for determine interaction of climate parameters on diameter increment.

Statistical analyses were done in the STATISTICA 12 software (StatSoft, Tulsa). Data were tested for normal distribution by the Kolmogorov-Smirnov test. Differences in the dominant height of trees, average height of recruits and radial increment were tested separately by one-way analysis of variance (ANOVA) for evaluation of differences between PRP and two main tree species. The significantly different results were then tested by the post-hoc HSD Tukey test. In addition, effects of air pollution data on diameter increment of beech and spruce and growth parameters with altitude were tested by the Pearson correlation coefficient. Variances are shown by standard deviation $( \pm \mathrm{SD})$. The principal component analysis (PCA) was performed in the CANOCO 5 programme (Microcomputer Power) to evaluate the interactions

Table 2. The indices describing stand structure and their common interpretation

\begin{tabular}{|c|c|c|c|c|}
\hline Criterion & Quantifiers & Label & Reference & Evaluation \\
\hline Vertical diversity & Arten-profil index & $A$ (Pri) & Pretzsch, 2006 & $\begin{array}{l}\text { range } 0-1 \text {; balanced vertical structure } A<0.3 \text {; } \\
\text { selection forest } A>0.9\end{array}$ \\
\hline $\begin{array}{l}\text { Structural differ- } \\
\text { entiation }\end{array}$ & $\begin{array}{l}\text { Diameter dif. } \\
\text { Height dif. }\end{array}$ & $\begin{array}{l}T M_{d}(\mathrm{Fi}) \\
T M_{h}(\mathrm{Fi})\end{array}$ & Füldner, 1995 & $\begin{array}{l}\text { range } 0-1 ; \text { low } T M<0.3 \text {; } \\
\text { very high differentiation } T M>0.7\end{array}$ \\
\hline \multirow{2}{*}{$\begin{array}{l}\text { Horizontal struc- } \\
\text { ture }\end{array}$} & $\begin{array}{l}\text { Index of non-ran- } \\
\text { domness }\end{array}$ & $\alpha(\mathrm{P} \& \mathrm{Mi})$ & Mountford, 1961 & $\begin{array}{l}\text { mean value } \alpha=1 \text {; aggregation } \alpha>1 \text {; } \\
\text { regularity } \alpha<1\end{array}$ \\
\hline & Aggregation index & $R(\mathrm{C} \& \mathrm{Ei})$ & Clark \& Evans, 1954 & $\begin{array}{l}\text { mean value } R=1 \text {; aggregation } R<1 \\
\text { regularity } R>1\end{array}$ \\
\hline $\begin{array}{l}\text { Complex diver- } \\
\text { sity }\end{array}$ & Stand diversity & $B(\mathrm{~J} \& \mathrm{Di})$ & $\begin{array}{l}\text { Jaehne \& Dohrenbusch, } \\
1997\end{array}$ & $\begin{array}{l}\text { monotonous structure } B<4 \text {; uneven structure } B=6-8 \\
\text { very diverse structure } B>9\end{array}$ \\
\hline
\end{tabular}



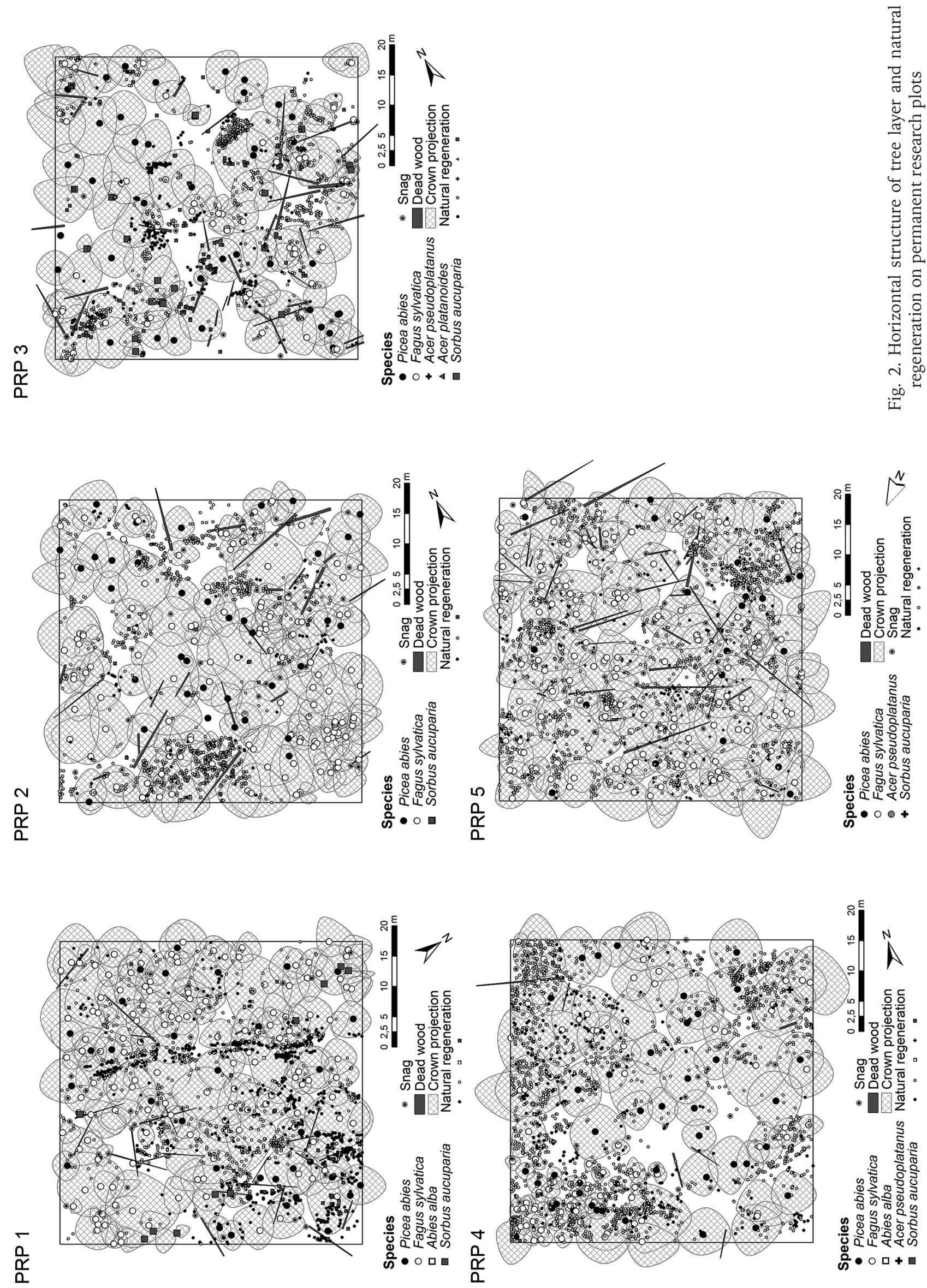
Table 3. The indices describing tree layer biodiversity on permanent research plots

\begin{tabular}{|c|c|c|c|c|c|c|c|c|c|c|c|c|c|}
\hline PRP & Year & A (Pri) & & $\mathrm{TM}_{\mathrm{d}}(\mathrm{Fi})$ & & $\mathrm{TM}_{\mathrm{h}}(\mathrm{Fi})$ & & $\mathrm{R}(\mathrm{C} \& \mathrm{Ei})^{*}$ & & $\alpha(\mathrm{P} \& \mathrm{Mi})^{*}$ & & B (J\&Di) & \\
\hline \multirow{2}{*}{1} & 2014 & 0.663 & \multirow[b]{2}{*}{$\searrow$} & 0.455 & \multirow{2}{*}{$\pi$} & 0.367 & \multirow{2}{*}{$\pi$} & $1.127^{\mathrm{R}}$ & \multirow{2}{*}{$\searrow$} & 0.902 & \multirow{2}{*}{$\pi$} & 7.427 & \multirow{2}{*}{ ע } \\
\hline & 2054 & 0.536 & & 0.674 & & 0.487 & & 1.068 & & 0.985 & & 7.229 & \\
\hline \multirow{2}{*}{2} & 2014 & 0.781 & \multirow{2}{*}{$\lambda$} & 0.413 & \multirow{2}{*}{$\pi$} & 0.334 & \multirow{2}{*}{$\searrow$} & 1.004 & \multirow{2}{*}{$\searrow$} & 1.144 & \multirow{2}{*}{$\pi$} & 7.006 & \multirow{2}{*}{ ע } \\
\hline & 2054 & 0.824 & & 0.466 & & 0.295 & & 0.991 & & 1.129 & & 6.204 & \\
\hline \multirow{2}{*}{3} & 2014 & 0.603 & \multirow{2}{*}{$\lambda$} & 0.440 & \multirow{2}{*}{$\pi$} & 0.327 & \multirow[b]{2}{*}{$\searrow$} & $0.891^{\mathrm{A}}$ & \multirow{2}{*}{$\pi$} & 1.612 & \multirow[b]{2}{*}{ 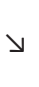 } & 7.232 & \multirow{2}{*}{$\searrow$} \\
\hline & 2054 & 0.622 & & 0.496 & & 0.302 & & 0.956 & & 1.576 & & 7.100 & \\
\hline \multirow{2}{*}{4} & 2014 & 0.572 & \multirow{2}{*}{$\lambda$} & 0.284 & \multirow{2}{*}{$\pi$} & 0.186 & \multirow{2}{*}{$\searrow$} & 0.912 & \multirow{2}{*}{$\lambda$} & 1.052 & \multirow{2}{*}{ オ } & 8.047 & \multirow{2}{*}{ y } \\
\hline & 2054 & 0.731 & & 0.299 & & 0.161 & & 1.007 & & 1.104 & & 5.629 & \\
\hline \multirow[b]{2}{*}{5} & 2014 & 0.721 & \multirow[b]{2}{*}{$\searrow$} & 0.345 & \multirow{2}{*}{$\pi$} & 0.241 & \multirow[b]{2}{*}{$\searrow$} & $0.933^{\mathrm{A}}$ & \multirow{2}{*}{$\pi$} & 1.227 & \multirow[b]{2}{*}{$\searrow$} & 6.566 & \multirow{2}{*}{$\searrow$} \\
\hline & 2054 & 0.674 & & 0.396 & & 0.225 & & 0.985 & & 1.204 & & 5.965 & \\
\hline
\end{tabular}

Notes: A - Arten-profil index, $\mathrm{TM}_{\mathrm{d}}$ - index of diameter differentiation, $\mathrm{TM}_{\mathrm{h}}$ - index of height differentiation, $\mathrm{R}$ - index of aggregation, $\alpha$-index of non-randomness, B - stand diversity index.

${ }^{*}$ statistically significant for horizontal structure ( ${ }^{\mathrm{A}}$ - aggregation, ${ }^{\mathrm{R}}$ - regularity); changes: $\searrow-$ decrease, $\lambda$ - increase.

between habitat conditions, climate characteristics, stand production characteristics, structural diversity and similarity of five plots under different hilltop phenomenon in the course of time. Data were log-transformed, centred and standardized before the analysis.

\section{Results}

\section{Structural diversity of tree layer}

Vertical structure consisting of three storeys was highly diversified on PRP $(A=0.668 \pm 0.167 \mathrm{SD})$, on PRP 3 it was almost selection structure (Tab. 3). TMd index showed stands with medium diameter differentiation $(T M d=0.387 \pm 0.040$ SD; Tab. 3) similarly like in height differentiation $(T M h=$ 0.186-0.367), except for low differentiation on PRP $4(T M h=0.186$; Tab. 3$)$. Indices of total stand diversity showed uneven structure $(B=6.566-8.047$; Tab. 3). In all above-mentioned indices, with the exception of vertical structure, the studied structural indices were the highest on PRP 1. According to the $\alpha$ index the tree layer individuals were distributed randomly (Fig. 2). On PRP 3 and 5 with moderately worse soil and climatic conditions (the influence of
PRP 1

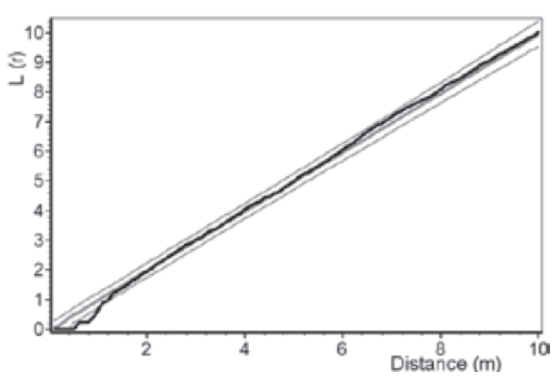

PRP 4

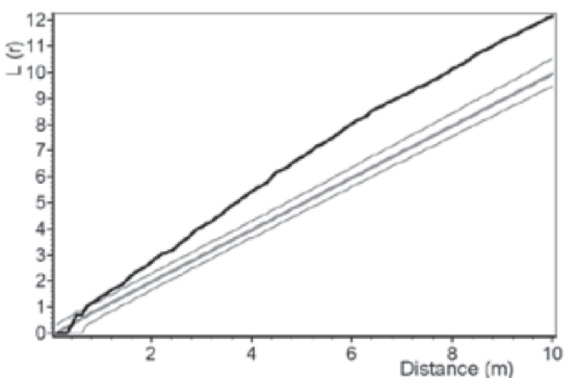

PRP 2

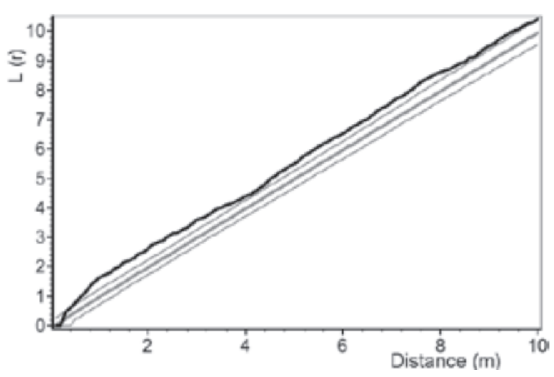

PRP 5

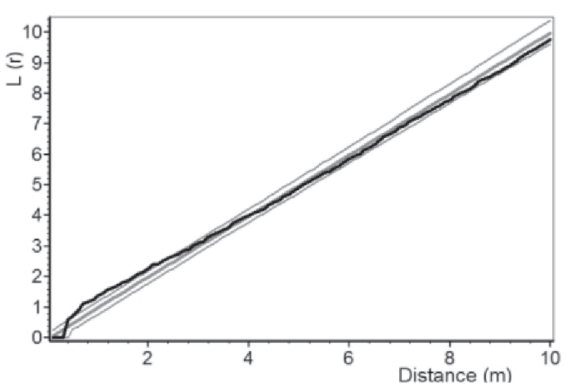

PRP 3

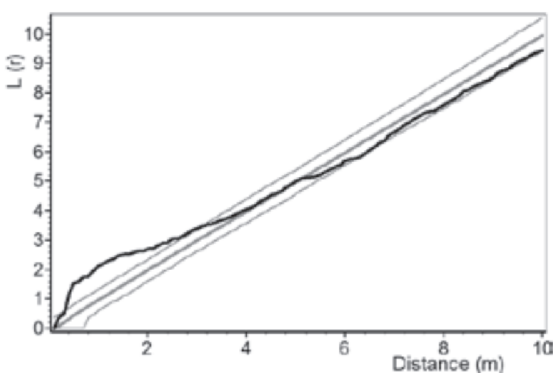

Fig. 3. Horizontal structure of tree layer on permanent research plots expressed by the $L$-function; the bold grey line represents the mean course for random spatial distribution of trees and the two thinner central curves represent $95 \%$ interval of reliability; when the black line of tree distribution on PRP is below this interval, it indicates a tendency of trees toward regular distribution, and if it is above this interval, it shows a tendency toward aggregation 
hilltop phenomenon) the $R$ index indicated an aggregated pattern, but the spatial pattern on PRP 1, which was situated at the lowest altitude, was significantly regular (Tab. 3). Aggregated structure was also confirmed by the $L$-function on PRP 3 to a distance of $2.5 \mathrm{~m}$, on PRP 5 from 0.5 to $2.5 \mathrm{~m}$ and on PRP 2 and 4 the aggregated structure was significant within $12 \mathrm{~m}$ (Fig. 3). The pattern of the upper storey was random inclining towards regularity, but trees in the lower storey showed an aggregated spatial pattern. The simulation of spontaneous development showed that diameter structure will be more and more diversified, on the other hand, there will be a decrease in total stand diversity. Aggregation indices will gradually approach the random Poisson distribution during 40 years.

\section{Stand condition and model development}

Currently, on PRP there were spatio-temporally differentiated mixed stands with dominant European beech (beech $55-88 \%$, spruce $12-33 \%$, rowan 0-13\%) at the stage of the optimum or initial break-up. Stand density index of the tree layer was on average 0.72 $( \pm 0.11 \mathrm{SD})$, crown projection area 2.42 ha $( \pm 0.36$ $\mathrm{SD})$ and canopy closure 0.90 ( $\pm 0.11 \mathrm{SD})$. The stand volume ranged from $239 \mathrm{~m}^{3} \mathrm{ha}^{-1}$ in the summit part at the highest altitude (PRP 3) to $536 \mathrm{~m}^{3} \mathrm{ha}^{-1}$ on a sloping terrain at the lowest altitude (PRP 1), both stands were of the same age (Tab. 4). An increase in stand volume by ca. $124 \mathrm{~m}^{3} \mathrm{ha}^{-1}( \pm 27 \mathrm{SD})$ is expected in 2054. The number of tree layer individuals ranged from 440 to 760 trees ha $\mathrm{h}^{-1}$ and basal area from 36.2 to $50.4 \mathrm{~m}^{2}$ ha ${ }^{-1}$ with maximum values on PRP 5 . Within 40 years there will be an increase in the tree layer individuals by ca. $12.2 \%$. In 2014 periodic annual increment was 3.0-8.8 $\mathrm{m}^{3} \mathrm{ha}^{-1} \mathrm{y}^{-1}$ and mean annual increment amounted to $1.3-3.9 \mathrm{~m}^{3} \mathrm{ha}^{-1} \mathrm{y}^{-1}$.

The representation of diameter classes on PRP 1 and 4 roughly corresponded to the shape of Liocourt curve with the highest abundance of 196 and 188

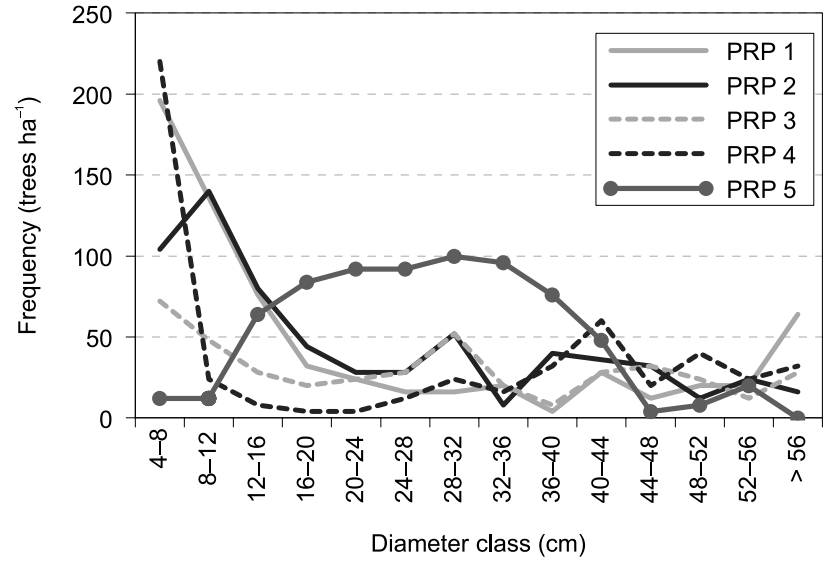

Fig. 4. Histogram of diameter classes of the tree layer on PRP 1-5

trees $\mathrm{ha}^{-1}$ in the class of 4-8 cm (Fig. 4). Spruce representation in diameter classes was uneven on these two PRP (2 and 4), diameter structure of beech indicated the exponential decay curve, characteristic of selection forest. The left-skewed shape of histogram also applied to PRP 2 and 3. Tree distribution in diameter classes on PRP 5 was typical of the stage of the optimum with the majority of trees of $20-36 \mathrm{~cm}$ in dbh.

In general, classes with $\mathrm{dbh}>76 \mathrm{~cm}$ were also represented on PRP. Spruce occurs mainly in larger diameter classes (dbh $>20 \mathrm{~cm}$ ). Rowan occurs mainly in thinner classes, only on PRP 3 there were individuals up to $36 \mathrm{~cm}$ in $\mathrm{dbh}$. Spruce trees were dominant trees with maximum height of $36.8 \mathrm{~m}$ while beech trees were not taller than $33.1 \mathrm{~m}$ (on PRP 1). A comparison of diameter histograms after model simulation after 40 years indicated a typical shift from lower to higher diameter classes but the initial diameter classes continued to show the highest abundances (except PRP 3). The greatest changes were observed in rowan (a pronounced increase in the class of 4-12 cm) and there was a decline of spruce and beech individuals with $\mathrm{dbh}>64 \mathrm{~cm}$.

Table 4. Basic stand characteristics of PRP in 2014 and simulated development in 2054

\begin{tabular}{|c|c|c|c|c|c|c|c|c|c|c|c|c|}
\hline PRP & Year & $\begin{array}{c}\mathrm{t} \\
(\mathrm{y})\end{array}$ & $\begin{array}{c}\mathrm{dbh} \pm \mathrm{SD} \\
(\mathrm{cm})\end{array}$ & $\begin{array}{c}\mathrm{h} \\
(\mathrm{m})\end{array}$ & $\mathrm{f}$ & $\begin{array}{c}\mathrm{v} \\
\left(\mathrm{m}^{3}\right)\end{array}$ & $\begin{array}{c}\mathrm{N} \\
\left(\text { trees ha }^{-1}\right)\end{array}$ & $\begin{array}{c}\mathrm{G} \\
\left(\mathrm{m}^{2} \mathrm{ha}^{-1}\right)\end{array}$ & $\begin{array}{c}\mathrm{V} \\
\left(\mathrm{m}^{3} \mathrm{ha}^{-1}\right)\end{array}$ & $\mathrm{h}: \mathrm{d}$ & $\begin{array}{c}\text { PAI } \\
\left(\mathrm{m}^{3} \mathrm{ha}^{-1} \mathrm{y}^{-1}\right)\end{array}$ & $\begin{array}{c}\text { MAI } \\
\left(\mathrm{m}^{3} \mathrm{ha}^{-1} \mathrm{y}^{-1}\right)\end{array}$ \\
\hline \multirow[t]{2}{*}{1} & 2014 & 161 & $29.3 \pm 19.8$ & 15.15 & 0.750 & 0.766 & 700 & 47.0 & 536 & 51.7 & 7.2 & 3.33 \\
\hline & 2054 & 194 & $36.9 \pm 24.4$ & 19.10 & 0.60 & 1.217 & 532 & 56.7 & 648 & 51.8 & 6.6 & 4.18 \\
\hline \multirow[t]{2}{*}{2} & 2014 & 157 & $27.4 \pm 15.8$ & 12.51 & 0.630 & 0.464 & 652 & 38.5 & 303 & 45.7 & 5.5 & 1.93 \\
\hline & 2054 & 181 & $34.1 \pm 18.5$ & 14.11 & 0.54 & 0.696 & 488 & 44.5 & 340 & 41.4 & 4.8 & 2.78 \\
\hline \multirow[t]{2}{*}{3} & 2014 & 165 & $32.5 \pm 17.5$ & 12.27 & 0.534 & 0.543 & 440 & 36.4 & 239 & 37.8 & 3.0 & 1.45 \\
\hline & 2054 & 211 & $42.2 \pm 23.5$ & 13.49 & 0.474 & 0.894 & 324 & 45.2 & 290 & 32.0 & 2.6 & 1.79 \\
\hline \multirow[t]{2}{*}{4} & 2014 & 139 & $32.7 \pm 20.3$ & 14.53 & 0.654 & 0.798 & 516 & 43.3 & 412 & 44.4 & 6.7 & 2.96 \\
\hline & 2054 & 185 & $47.1 \pm 19.5$ & 19.75 & 0.485 & 1.667 & 340 & 59.0 & 567 & 41.9 & 6.4 & 3.99 \\
\hline \multirow[t]{2}{*}{5} & 2014 & 122 & $29.0 \pm 10.4$ & 18.64 & 0.502 & 0.618 & 760 & 50.4 & 470 & 64.3 & 8.8 & 3.85 \\
\hline & 2054 & 159 & $39.7 \pm 15.1$ & 21.6 & 0.483 & 1.292 & 480 & 59.5 & 620 & 54.4 & 8.4 & 5.19 \\
\hline
\end{tabular}

Notes: $\mathrm{t}$ - average stand age, $\mathrm{dbh}$ - mean quadratic breast height diameter, $\mathrm{h}$ - mean height, $\mathrm{v}-$ mean tree volume, $\mathrm{N}$ - number of trees, $\mathrm{G}$ - basal area, V - stand volume, h:d - slenderness ratio, PAI - periodic annual increment, MAI - mean annual increment. 


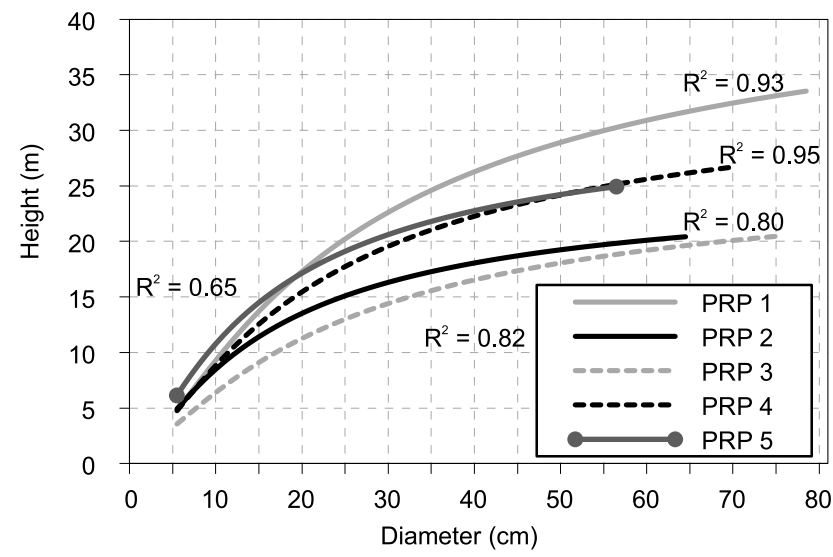

Fig. 5. A relationship between breast height diameter and tree height with coefficient of determination $\left(\mathrm{R}^{2}\right)$ on PRP 1-5

The relationship between $\mathrm{dbh}$ and tree height showed a relatively pronounced correlation (Fig. 5). It was to note that the highest trees on PRP 3 and 4 did not exceed the height of $17-21 \mathrm{~m}$ in beech and $22 \mathrm{~m}$ in spruce, which was caused by the pronounced hilltop phenomenon. On the contrary, on PRP 1 these heights were $33 \mathrm{~m}$ in beech and $37 \mathrm{~m}$ in spruce due to protection against the pronounced hilltop phenomenon by Vrchmezí Mts. The dominant height (comparing trees with $\mathrm{h} \geq \mathrm{h}_{90 \%_{0}}$ ) decreased with increasing altitude and/or with the influence of hilltop phenomenon $(\mathrm{r}=-0.97$; $\mathrm{P}<0.001)$. Comparing differences between plots, there were significant differences in dominant heights between both trees species (beech $\mathrm{F}_{(4,53)}=113.3$, spruce $\mathrm{F}_{(4,15)}=141.7$, P $<0.001)$. Significantly the highest dominant height was on PRP 1 in beech $(29.5 \mathrm{~m} \pm 0.4 \mathrm{SD})$ and spruce $(34.9 \mathrm{~m} \pm 0.5 \mathrm{SD})$ and the lowest in beech on PRP 3 $(17.2 \mathrm{~m} \pm 0.6 \mathrm{SD})$ and in spruce on PRP $2(20.9 \mathrm{~m}$ $\pm 0.5 \mathrm{SD})$ and PRP $3(21.3 \mathrm{~m} \pm 0.5 \mathrm{SD} ; \mathrm{P}<0.05)$.

\section{Dynamics of radial growth}

In the studied area average radial increment did not differ very much when the plots were compared; average tree-ring width on PRP 2 was $1.3 \mathrm{~mm}$ ( \pm $0.3 \mathrm{SD}$ ) in beech and $1.5 \mathrm{~mm}( \pm 0.5 \mathrm{SD})$ in spruce, on PRP 1 with the lowest altitude it was the highest increment $1.9 \mathrm{~mm}( \pm 0.8 \mathrm{SD})$ in beech and the lowest $1.0 \mathrm{~mm}( \pm 0.4 \mathrm{SD})$ in spruce, on PRP 51.3 $\mathrm{mm}( \pm 0.3 \mathrm{SD})$ in beech and $1.3 \mathrm{~mm}( \pm 0.53 \mathrm{SD})$ in spruce, on PRP 3 under the strong hilltop phenomenon the values were the lowest $1.2 \mathrm{~mm}( \pm 0.3 \mathrm{SD})$ in beech and conversely the highest $1.9 \mathrm{~mm}( \pm 0.4 \mathrm{SD})$ in spruce, and on PRP 4 the values for beech were 1.4
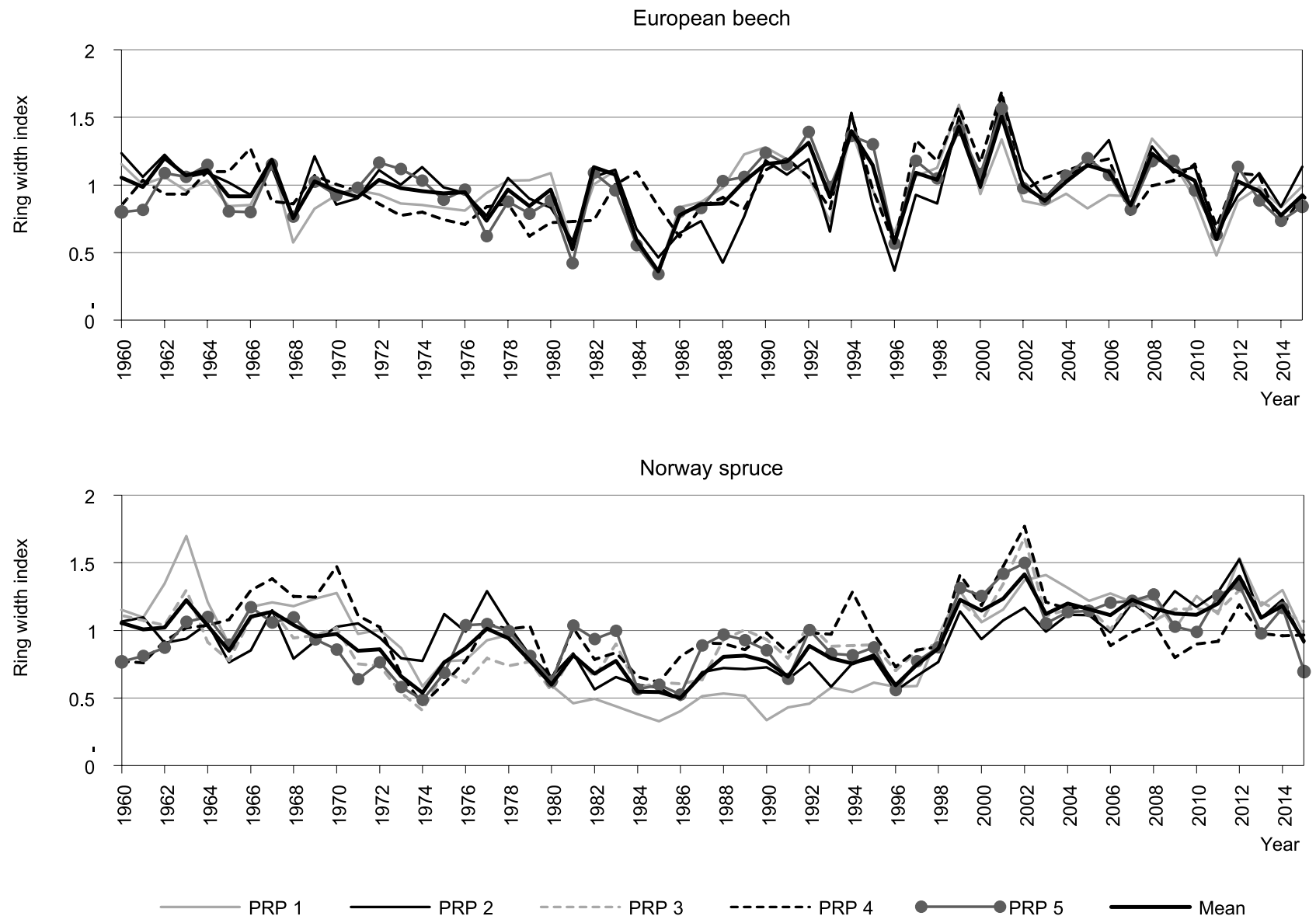

Fig. 6. Standardized ring-width chronologies for beech and spruce after removing the age trend 
$\mathrm{mm}( \pm 0.4 \mathrm{SD})$ and for spruce $1.7 \mathrm{~mm}( \pm 0.5 \mathrm{SD})$. The regional standardized ring-width chronology of beech showed a relatively balanced radial increment in 1960-1980, and subsequently there was a trend of its wavelike fluctuation (Fig. 6). In spruce the relatively balanced trend of increment already ended in 1970, its fluctuating decrease followed until 1999 and since 2000 there has been a marked increase in increment with the exception of 2015 (Fig. 6). The years with low radial increment were confirmed by the analysis of negative pointer years for beech 1911, 1913, 1928, 1952, 1953, 1981, 1985, 1996, 2011 and for spruce 1974 and 1980.

A comparison of average tree-ring curves for PRP indicated their high mutual correspondence when the t-test $\geq 3.4$ showed the reliability of synchronization. After the division of ring-width curves for three seasons according to air pollution load (before 19551978, during 1978-1998 and after $\mathrm{SO}_{2}$ load 19982014), there were significant differences between these periods and trees species $\left(\mathrm{F}_{(5,614)}=39.51 ; \mathrm{P}\right.$ $<0.001$ ). Before 1978 similarity of the ring-width index was found between beech (0.95) and spruce (0.95; P > 0.05), but in the period 1978-1998 beech trees had significantly higher increment (0.93) than spruce $(0.75 ; \mathrm{P}<0.001)$. After pollution load diameter increment improved in both tree species, but there are still significant differences (beech 1.05; spruce 1.16; $\mathrm{P}<0.001)$. Comparing radial growth between periods before, during and after $\mathrm{SO}_{2}$ load, there was similarity in beech $(\mathrm{P}>0.05)$, but a significant difference was found in spruce $(\mathrm{P}<0.001)$.

Correlations of beech diameter increment with average monthly temperatures and precipitation showed some statistically significant values. In 1963-2014 in the Orlické hory Mts. beech diameter increment indicated statistically significant positive correlations with temperature in July and August of the preceding year and April of the current year $(r=0.40, r=0.23, r=0.32$; Fig. 7$)$. There were also statistically significant positive correlations with precipitation amount in March and negative correlations with precipitation amount in July of the current year $(r=0.28,-0.24$; Fig. 7$)$.

European beech
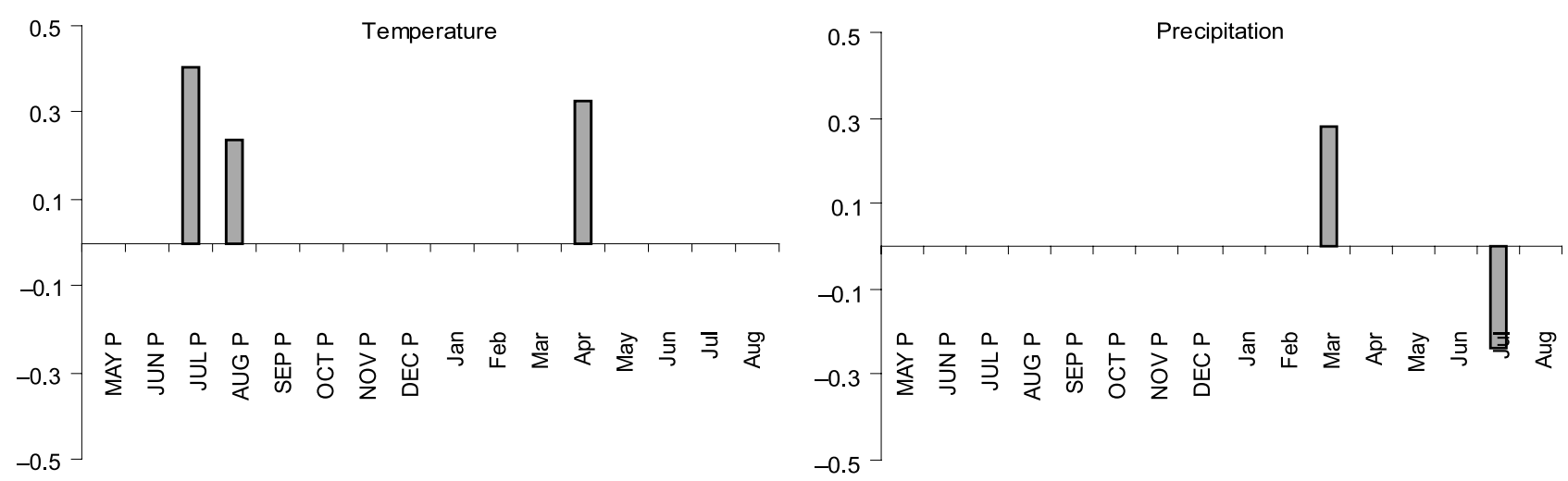

Norway spruce
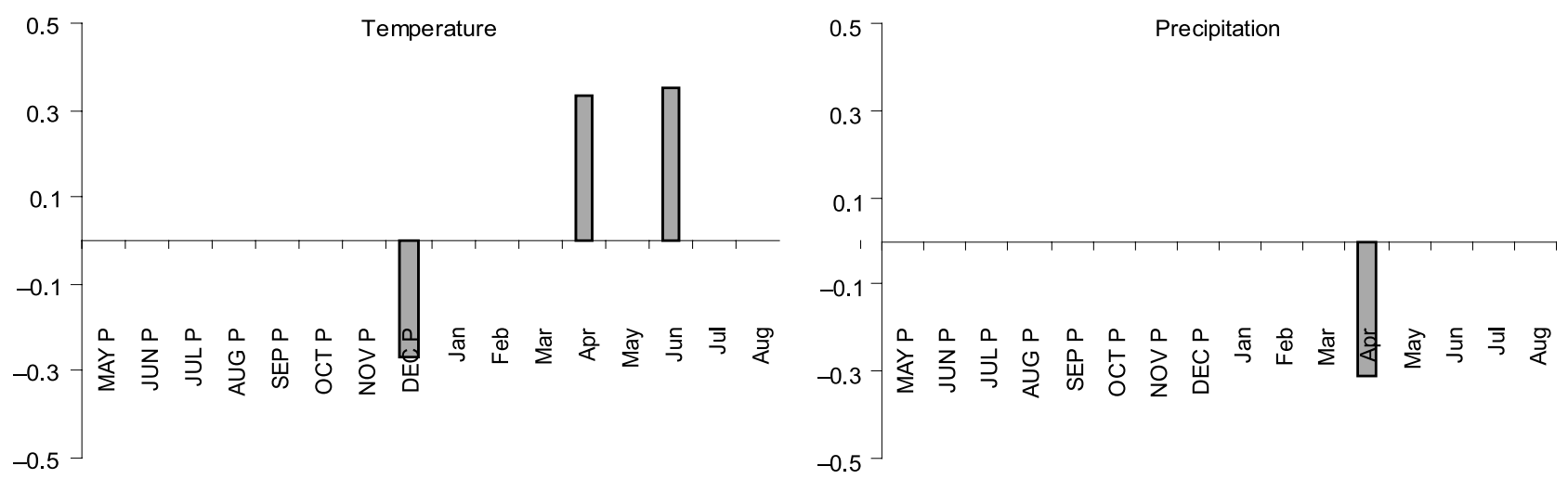

Fig. 7. The values of correlation coefficients of the regional residual index tree-ring chronology with the mean monthly temperature (on the left) and amount of precipitation (on the right) from May of the previous year (P) to September of the current year for the period 1963-2013 for beech and for spruce; values are statistically significant $(\alpha=0.05)$ 
Table 5. Correlations between radial growth increment and air pollution factors $\left(\mathrm{SO}_{2}\right.$ in 1971-2014; $\mathrm{NO}_{\mathrm{x}}$ in 1992-2012) for beech and for spruce

\begin{tabular}{|c|c|c|c|c|c|c|c|c|}
\hline \multirow{2}{*}{ PRP } & \multicolumn{4}{|c|}{ European beech } & \multicolumn{4}{|c|}{ Norway spruce } \\
\hline & $\mathrm{SO}_{2}$ mean & $\mathrm{SO}_{2} \max$ & $\mathrm{NO}_{\mathrm{x}}$ mean & $\mathrm{NO}_{\mathrm{x}} \max$ & $\mathrm{SO}_{2}$ mean & $\mathrm{SO}_{2} \max$ & $\mathrm{NO}_{\mathrm{x}}$ mean & $\mathrm{NO}_{\mathrm{x}} \max$ \\
\hline 1 & -0.081 & -0.206 & 0.141 & -0.240 & $-0.637^{* *}$ & $-0.694^{* *}$ & $-0.767^{* *}$ & $-0.596^{* *}$ \\
\hline 2 & -0.290 & $-0.516^{* *}$ & -0.114 & -0.436 & $-0.563^{* *}$ & $-0.571^{* *}$ & $-0.807^{* *}$ & $-0.585^{* *}$ \\
\hline 3 & -0.168 & $-0.346^{*}$ & 0.163 & -0.240 & $-0.672^{* *}$ & $-0.651^{* *}$ & $-0.505^{*}$ & $-0.448^{*}$ \\
\hline 4 & -0.305 & $-0.419^{* *}$ & 0.176 & -0.251 & $-0.495^{* *}$ & $-0.533^{* *}$ & -0.097 & -0.135 \\
\hline 5 & -0.062 & -0.252 & 0.260 & -0.118 & $-0.747^{* *}$ & $-0.680^{* *}$ & $-0.555^{* *}$ & $-0.542^{*}$ \\
\hline All & -0.168 & $-0.346^{*}$ & 0.163 & -0.240 & $-0.740^{* *}$ & $-0.739 * *$ & $-0.700^{* *}$ & $-0.600^{* *}$ \\
\hline
\end{tabular}

Notes: Significant correlations $(\mathrm{P}<0.05)$ are indicated with * and $(\mathrm{P}<0.01)$ with ${ }^{* *}$; $\mathrm{SO}_{2}\left(\mathrm{NO}_{\mathrm{X}}\right)$ mean - mean annual $\mathrm{SO}_{2}$ concentration, $\mathrm{SO}_{2}\left(\mathrm{NO}_{\mathrm{x}}\right)$ max - maximum daily $\mathrm{SO}_{2}$ concentrations.

In 1963-2012 in the Orlické hory Mts. spruce diameter increment showed statistically significant correlations with temperature in December of the previous year and in April and June of the current
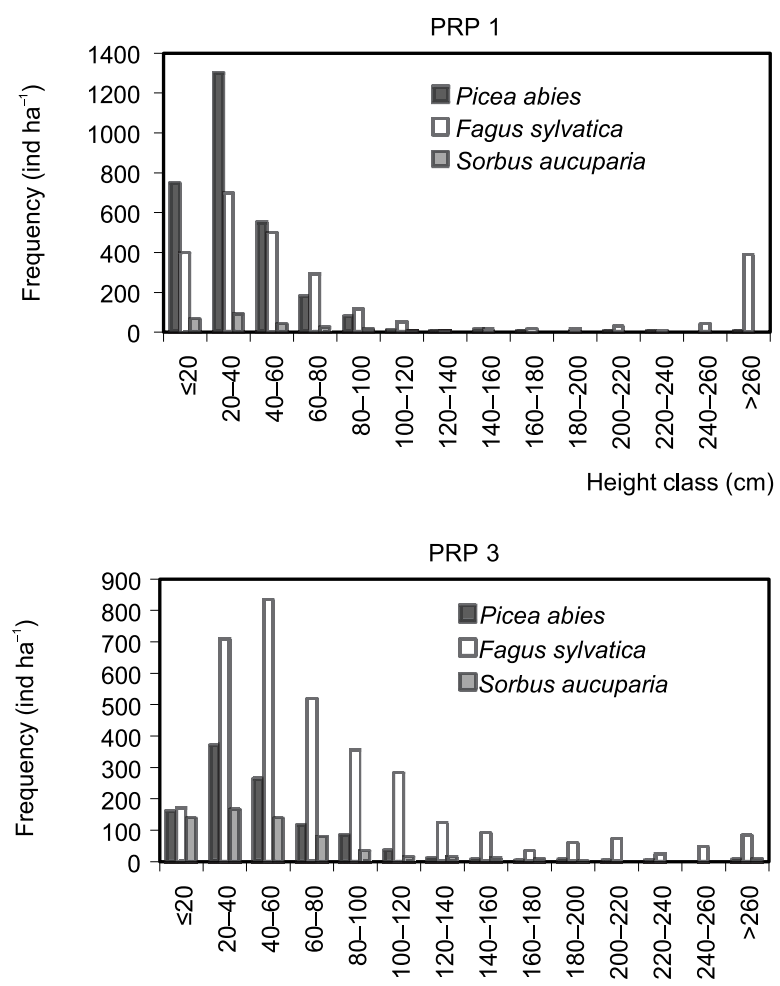

Height class $(\mathrm{cm})$

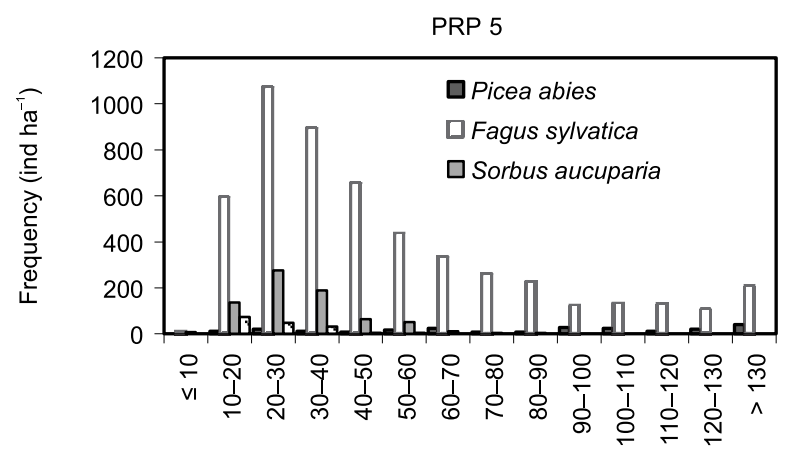

Height class $(\mathrm{cm})$ year $(r=-0.27 ; r=0.33, r=0.35$; Fig. 7). Statistically significant negative correlations with precipitation amount in April of the current year were also found out $(\mathrm{r}=-0.31$; Fig. 7$)$.
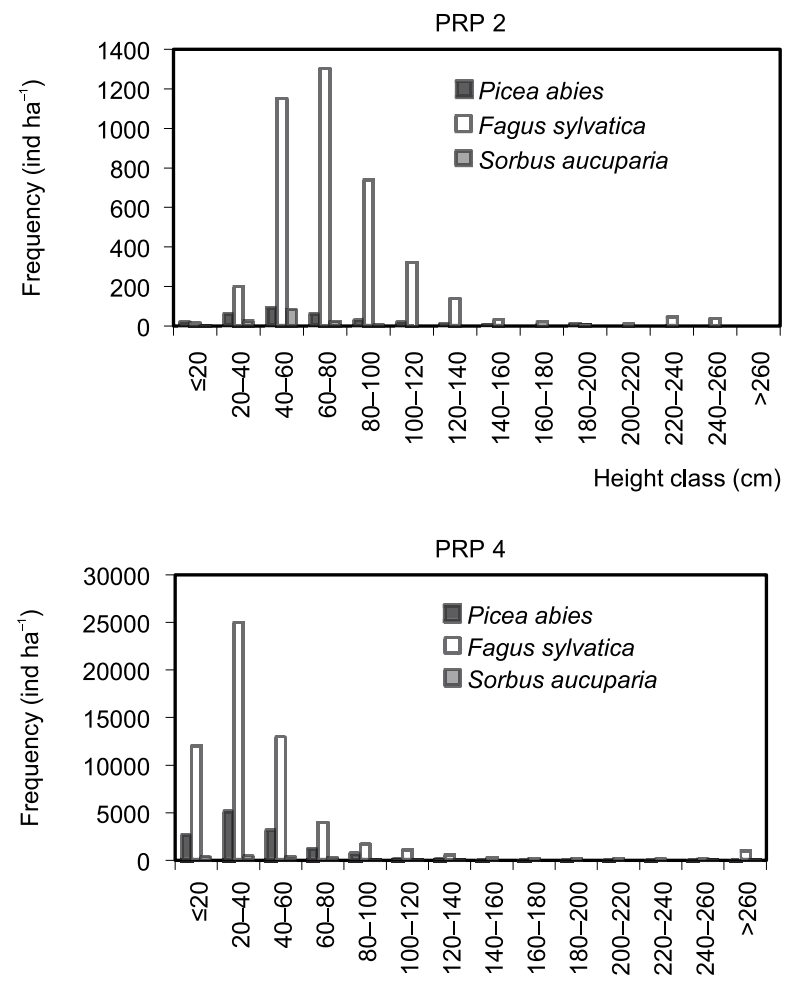

Heigth class $(\mathrm{cm})$

Fig. 8. Histogram of the height classes of natural regeneration of main tree species on permanent research plots 
The radial growth increment of spruce showed significant negative correlations with mean annual $\mathrm{SO}_{2}$ concentrations and maximum daily $\mathrm{SO}_{2}$ concentrations, especially on exposed PRP 1,3 and $5(\mathrm{P}<$ 0.001; Tab. 5). In terms of monthly $\mathrm{SO}_{2}$ concentrations (1971-2011), the highest significant negative correlation of radial growth was found out for April $(P<0.001)$ and the lowest for December $(P<0.01)$. Radial growth of spruce was also negatively correlated with $\mathrm{NO}_{\mathrm{x}}$ concentrations $(\mathrm{P}<0.05-0.001)$ except PRP $4(\mathrm{P}>0.05)$. Conversely, no significant correlations with mean annual $\mathrm{SO}_{2}$ concentrations were determined for beech $(\mathrm{P}>0.05)$, but diameter increment was significantly negatively correlated with maximum daily $\mathrm{SO}_{2}$ concentrations on PRP 3 ( $\mathrm{P}<$ 0.05), PRP $4(\mathrm{P}<0.01)$ and PRP $2(\mathrm{P}<0.001) . \mathrm{NO}_{\mathrm{x}}$ concentrations had no significant effect on radial growth of beech $(\mathrm{P}<0.05)$.

\section{Dead wood}

The total volume of dead wood (DW) ranged from 6.1 (PRP 4) and/or 59.3 (RPP 2) to $112.1 \mathrm{~m}^{3} \mathrm{ha}^{-1}$ (PRP 5), because on PRP 4 all DW was cleared. The volume of lying dead wood on PRP ranged from 5.0 $\mathrm{m}^{3} \mathrm{ha}^{-1}$ (PRP 4) to $83.6 \mathrm{~m}^{3} \mathrm{ha}^{-1}$ (PRP 1) and accounted for $73.4-83.2 \%$ of the total quantity of standing and lying DW. DW accounted for $1.0-24.2 \%$ of the volume of the whole stand (live and dead trees). Degree 2 and 3 of wood decomposition had the highest proportion in standing DW. In lying DW more advanced stages of decomposition prevailed (degree 3 and 4); the occurrence of degree 1 was only minimal there. Based on the simulation of spontaneous development it is to expect that in 2054 the mean volume of dead wood will increase to $138.5 \mathrm{~m}^{3} \mathrm{ha}^{-1}$ ( $\pm 46.9 \mathrm{SD})$.

\section{Natural regeneration}

The number of natural regeneration individuals ( $h$ $\geq 10 \mathrm{~cm}$ ) on PRP was in the range of 4584 (PRP 2) to 73740 (PRP 4) recruits ha ${ }^{-1}$; beech accounted for $44.9-91.2 \%$, spruce for $6.3-50.6 \%$, rowan $2.4-12.3 \%$ and sycamore maple with silver fir $<1 \%$. The height structure of natural regeneration was left-skewed and the highest number of recruits belonged to classes from 20 to $100 \mathrm{~cm}(64.4-82.2 \%)$, on PRP 1 and 4 the height class $\leq 20 \mathrm{~cm}$ was also abundant (1220 and 9692 recruits ha $^{-1}$; Fig. 8). Natural regeneration with the highest age and height diversification was on PRP 3, the highest species diversity was on PRP 1 and 3 . Average height of individuals was markedly taller $\left(\mathrm{F}_{(3,5467)}=54.8, \mathrm{P}<0.001\right)$ on PRP $2(87.5 \mathrm{~cm}$ $\pm 2.3 \mathrm{SD})$ than on PRP $3(75.1 \mathrm{~cm} \pm 2.1 \mathrm{SD})$ and PRP $1(74.5 \mathrm{~cm} \pm 2.0 \mathrm{SD})$; the significantly smallest height was on PRP $5(51.1 \mathrm{~cm} \pm 1.9 \mathrm{SD})$.
The spatial pattern of regeneration was significantly aggregated on all plots according to $L$-functions and indices $(R=0.459-0.720, \alpha=2.749-9.108)$ with the highest tendency towards aggregatedness on PRP 2. Results of the pair cross-correlation analysis showed that the relationship between the spatial pattern of tree layer and natural regeneration was negative (regular) at smaller distances on PRP 1, 4 and 5 (from stem base to $0.6-6.1 \mathrm{~m}$ ). The spatial pattern at larger distances across the plots was mostly random to slightly aggregated (positive relationship). Conversely, on PRP 3 with the most extreme site conditions the spatial pattern of tree layer had a positive relationship with beech natural regeneration to a distance of $2.1 \mathrm{~m}$ (horizontal structure was aggregated).

\section{Relationship of habitat and stand conditions to structural diversity}

The results of PCA are presented as an ordination diagram in Fig. 9. The first ordination axis explains $33.5 \%$, the first two axes $57.9 \%$ and all four axes in total $89.5 \%$ of data variability. The first $\mathrm{x}$-axis represents stand volume, canopy and aggregation $R$ index. The second y-axis represents $\mathrm{dbh}$, stand age and $A$ index. Basal area, average height, stand volume, vertical diversity, share of spruce and dead wood volume increased in the course of time. An opposite trend occurred in total diversity. Structural differentiation

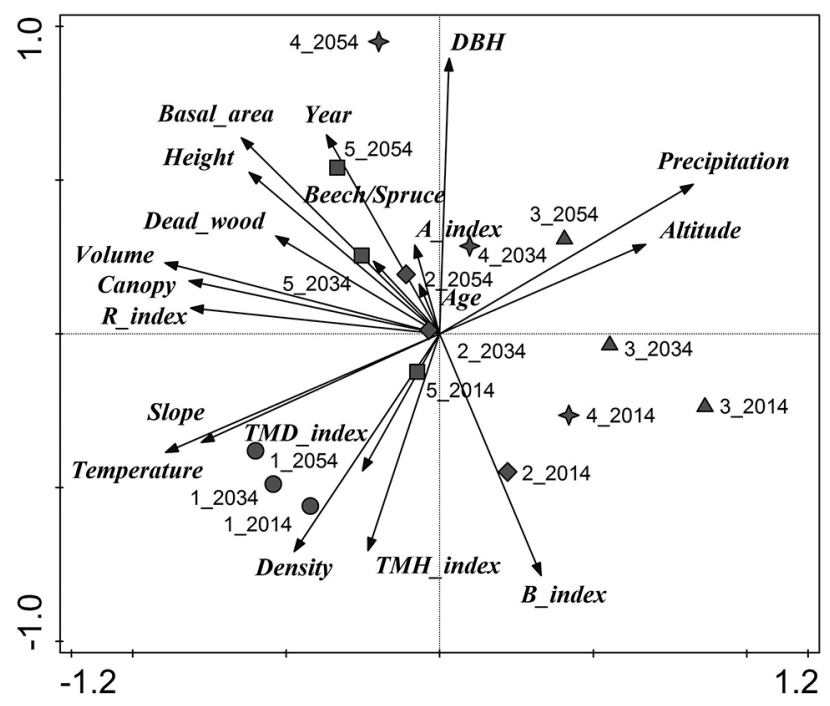

Fig. 9. Ordination diagram showing results of the PCA analysis of relationships between habitat attributes (Altitude, Slope, Temperature, Precipitation), stand characteristics (Age, Volume, Basal area, DBH, Height, Canopy, Density, Beech/Spruce proportion), structural diversity ( $A, T M d, T M h, R$ and $B$ indices) and dead wood volume in the course of time (Year); Codes: $\bullet, \nabla, \bullet, \mathbf{\square}, \downarrow$ indicate plots with the number of year records (20142054) 
indices (TMd, TMh index) positively correlated with stand density, while these parameters negatively correlated with mean dbh and altitude. Precipitation amount increased with the higher altitude while average temperature decreased and the stand structure turned from regular to clumpy pattern. The contributions of stand age, $A$ index and proportion of beech and spruce were relatively small. The dynamics of parameters in the course of 40 years was remarkable especially for PRP 4 as marks of each record were relatively distant from one another whereas marks for PRP 1 were fairly close together in the diagram.

\section{Discussion}

Structural dynamics of near-natural forest stands with dominant European beech and admixed Norway spruce in protected areas in the summit parts of the Orlické hory Mts. is a unique example of fragments of autochthonous stands left to spontaneous development in the area with the pronounced hilltop phenomenon with frequent incidence of heavy icing (cf. Kadlus, 1960; Kadlus \& Ř́ha, 1971; Vacek et al., 2012, 2014).

Tree layer individuals on PRP were distributed predominantly randomly, but on PRP under the strongest influence of hilltop phenomenon the indicators showed an aggregated spatial pattern. A similar horizontal structure of tree layer with dominant European beech like on these PRP was reported by Vacek et al. (2015b) from the Krkonoše National Park. Like in the Krkonoše Mts., this study of autochthonous stands also confirmed the positive influence of habitat extremes (altitude) on the aggregated spatial pattern of the overstorey (cf. Vacek et al., 2015b; Bulušek et al., 2016), but a small difference in altitude in our study and possible influences of past silvicultural management must be considered (Štefančík, 2015). This spatial model was revealed in other European natural forests with dominant beech (von Oheimb et al., 2005; Commarmot et al., 2005). The regularity of tree distribution in the overstorey was observed in beech stands in Slovenia (Rugani et al., 2013). Stands on PRP showed medium to high structural differentiation that decreased with increasing altitude. The prediction of spontaneous development showed that on the studied PRP diameter structure will be more and more diversified in the nearest decades but there will be a decrease in total diversity, which was found out in spruce-beech stands in Trčkov reserve in the Orlické hory Mts. (Vacek et al., 2014). Model development of the studied PRP created by the SIBYLA growth simulator, which confirmed a high accuracy (Špulák \& Souček, 2010; Vacek et al., 2015b), showed relative stability in the forest dynamics in the area of the hilltop phenomenon.
In terms of productivity, a similar stand volume like on the studied PRP in the Orlické hory Mts. (239-537 $\mathrm{m}^{3} \mathrm{ha}^{-1}$ ) was found out in comparable localities in the Krkonoše Mts. $\left(218-416 \mathrm{~m}^{3} \mathrm{ha}^{-1}\right.$ ) (Vacek et al., 2015b). It is lower in comparison with other near-natural beech forests in Europe due to worse climatic and especially soil conditions in summit areas of the mountains. E.g. Christensen et al. (2005) reported the average stand volume of $559 \mathrm{~m}^{3} \mathrm{ha}^{-1}$, Oheimb et al. (2005) $604 \mathrm{~m}^{3} \mathrm{ha}^{-1}$ and Meyer et al. (2003) even $715 \mathrm{~m}^{3} \mathrm{ha}^{-1}$. As for soil conditions, mostly strongly acidic forms prevail and mineralization predominates over immobilization on the studied PRP (Vacek et al., 1994). For the high C:N ratio, like on the studied plots, microbes compete with plants for mineral form of $\mathrm{N}$ and the plants suffer from $\mathrm{N}$ deficiency (Ernfors et al., 2007). Overall, the most extreme soil conditions were found on PRP 3, i.e. in the area with the most pronounced hilltop phenomenon. Similar soil conditions, like in the Orlické hory Mts., were reported in the Krkonoše Mts. (Matějka et al., 2010) and in other mountainous areas of the Sudeten system in the Czech Republic (Borůvka et al., 2005).

Average tree-ring width in European beech and Norway spruce ranged from 1.2 to $1.9 \mathrm{~mm}$ and from 1.0 to $1.9 \mathrm{~m}$, respectively. On PRP under the strong hilltop phenomenon radial growth was the lowest in beech and the highest in spruce; an opposite trend was observed on PRP at the lowest altitude. Higher radial increment of spruce compared to beech in spruce-beech stands was in southern Sweden (Bolte et al., 2010). Originally dominant diameter increment of spruce has decreased in the last 50 years, on the contrary in beech it has been constant or it has slightly increased. The minimum radial increment on PRP indicates more frequent ice-damage to beech crowns in comparison with spruce. The extreme incidence of icing in the summit parts of the Orlické hory Mts. was documented by Kadlus (1960, 1972) and Kadlus \& Ríha (1971). In the 80s of the $20^{\text {th }}$ century the minimum growth in both studied tree species was caused by the synergism of air pollutants and climate, which is a consistent conclusion with other studies (Jurásek \& Vacek, 1987; Vacek et al., 2015a). In 2015 the minimum growth of spruce was due to drought that occurred in two consecutive years. A pronounced effect of drought on spruce radial increment was also reported by Bolte et al. (2010). As a result of global climate changes in the summit parts of the Orlické hory Mts. the incidence of icing causing severe damage to beech crowns has considerably decreased; while in 1910-1970 it occurred 6 times, in 1970-2015 it occurred only once, i.e. 3.5 times less frequently. It has supported an increase in the competitiveness of beech in comparison with spruce. In 1981 and 1985 in beech and in 1980, 1984 
to 1986 in spruce low increment was caused by the synergism of air pollution and adverse climate, and/ or Cryptococcus fagi in beech. In 1996 severe ice-damage (the coldest winter since 1969 - mean temperature $-5.5^{\circ} \mathrm{C}$ ) to spruce tree crowns occurred (Vacek et al., 1994; Mareš et al., 1995; Balcar et al., 1994; Vacek et al., 2015a). In recent years (2015), damage by strong drought was accentuated in spruce (mean precipitation in GS in 1961-2014 $621 \mathrm{~mm}$, in 2015 only $337 \mathrm{~mm}$ ). In future, from an ecological aspect greater preference of beech to spruce is to be assumed which has become in the last years more and more vulnerable to not only existing but also incoming abiotic environmental factors. Moreover, it suffers from greater damage by insect pests and fungal pathogens. These findings are consistent with others studies (Von Lüpke et al., 2004; Bréda et al., 2006; Pichler \& Oberhuber, 2007; Bolte et al., 2010; Maaten-Theunissen \& Bouriaud, 2012).

Considering the effects of climatic factors (monthly temperature and precipitation) and air pollution ( $\mathrm{SO}_{2}$ and $\mathrm{NO}_{\mathrm{x}}$ concentrations) on radial growth of beech and spruce, several significant correlations were found. A close relation between climate and radial growth was documented by numerous researches conducted throughout Europe (Meyer \& Bräker, 2001; Mäkinen et al., 2002; Andreassen et al., 2006; Král et al., 2015; Vacek et al., 2015a); nevertheless, the climate change brings further questions and issues of the relation to be investigated. Similarly like in our study, the correlation between radial increment and temperature was stronger than in precipitation in the Krkonoše Mts. (Král et al., 2015). Conversely, at lower altitudes (549-794 $\mathrm{m}$ a.s.l.) the effect of precipitation on growth was prevailing (Rybníček et al., 2010). A positive effect of temperature increases with the increasing altitude, while the effect of precipitation decreases (Mäkinen et al., 2002; Andreassen et al., 2006; Hauck et al., 2012). In our study radial growth was most influenced by climatic factors in April of the current year. Diameter increment indicated the highest significant positive correlations with average monthly temperature in July of the preceding year for beech, and/or in June of the current year for spruce. Similar studies in Norway (Andreassen et al., 2006) and Switzerland (Meyer \& Bräker, 2001) showed that temperatures in June and July positively influenced the diameter increment of spruce. There were also statistically significant positive correlations with precipitation amount, especially in March of the current year for beech, and a negative correlation in April of the current year for spruce, the same as in the Krkonoše Mts. (Král et al., 2015).

The negative impact of air pollution on growth increment has been documented by many studies (e.g. Feliksik, 1995; Juknys et al., 2002). Our results showed that diameter increment of spruce was significantly negatively correlated with average $\mathrm{SO}_{2}$ and $\mathrm{NO}_{\mathrm{x}}$ concentrations, especially in April, but no significant effect on the radial growth of beech was observed. For beech only maximum daily $\mathrm{SO}_{2}$ concentrations significantly negatively correlated with growth. Similarly, other studies reported the negative influence of $\mathrm{SO}_{2}$ on basal area increment (Muzika et al., 2004) or on the ring width of spruce, especially in mountain areas (Hauck et al., 2012). Air pollution had a significantly higher negative effect on the growth of spruce on the hilltop than at a lower part of the hill. The summit parts of mountain areas are highly vulnerable to air pollution, especially spruce stands (Vacek et al., 2015a).

The total volume of DW was $6.1-112.1 \mathrm{~m}^{3} \mathrm{ha}^{-1}$ and this range was lower than that given by Christensen et al. (2005) from 86 beech reserves with the average value of $130 \mathrm{~m}^{3} \mathrm{ha}^{-1}$. The mean volume of lying DW was $30.5 \mathrm{~m}^{3} \mathrm{ha}^{-1}$, i.e. $73.4-83.2 \%$ of the total quantity of DW. It is to note that Christensen et al. (2005) reported up to $55 \%$ for mountain areas. Such a low percentage is a result of management practices in the past and/or of the removal of DW.

On PRP the numbers of natural regeneration individuals were from 4584 to 73740 recruits ha ${ }^{-1}$, which, compared to natural forests in Slovenia, are lower and also distinctly higher numbers - 11 65414615 recruits ha ${ }^{-1}$ (Nagel et al., 2006). However, the numbers of recruits in beech forests in northeastern Germany were on average 3202 recruits ha ${ }^{-1}$ (von Oheimb et al., 2005). Similarly like on the studied RPR, also in other papers (von Oheimb et al., 2005; Vacek et al., 2014) the distribution of regeneration was aggregated. On PRP with more favourable climatic and habitat conditions the parent stand had a significant negative effect on the spatial pattern of regeneration at a smaller distance (from stem base to $0.6-6.1 \mathrm{~m}$ ), but on PRP under the strong hilltop phenomenon trees had a positive effect to $2.1 \mathrm{~m}$ due to a better microsite under the protection of the tree layer (Vacek \& Hejcman, 2012). Similarly, a negative effect of parent trees on the distribution of recruits was confirmed at a distance from stem base to $1-2.5$ $\mathrm{m}$ in autochthonous herb-rich beech forests in the Broumovsko Hills (Bulušek et al., 2016).

\section{Conclusion}

The studied nature reserves under the influence of pronounced hilltop phenomenon in the Orlické hory Mts. belong to the most valuable remnants of natural forests in this area. The hilltop phenomenon has a significant effect on structural differentiation, radial growth, height of trees, stand production, spatial pattern between parent trees and recruits, and on 
the horizontal structure of tree layer. During growth dynamics the spatial pattern changes from the aggregated pattern of individuals in the growing-up stage to the random and regular distribution of individuals in the stage of the optimum, similarly there are changes in horizontal structure with the decreasing influence of the hilltop phenomenon. The growth model indicates that the lowest dynamics was observed in stands without the effect of this phenomenon. As for climatic factors, low temperatures in the growing season are limiting factors for radial growth in the studied mountain area, but it is only slightly negatively affected by precipitation. Growth analyses show that with advancing global climate changes the European beech enhances its competitiveness in relation to Norway spruce that moreover is very vulnerable to air pollution in these summit areas. $\mathrm{SO}_{2}$ and $\mathrm{NO}_{\mathrm{x}}$ concentrations caused a significant decline in the tree growth of spruce, especially in 1979-1998 due to interaction between strong air pollution and climatic stresses. Better conditions are created for beech, both for natural regeneration and for the growth and development relations in the tree layer. This situation should be exploited when increasing the beech proportion at the cost of spruce in similar habitat and stand conditions.

\section{Acknowledgement}

This paper was written thanks to support of specific research No. 2112 realized in 2015 at the Faculty of Science of the University of Hradec Králové and Internal Grant Agency No. B02/16, Faculty of Forestry and Wood Sciences, Czech University of Life Sciences in Prague.

\section{References}

Ambrož R, Vacek S, Vacek Z, Král J \& Štefančík I (2015) Current and simulated structure, growth parameters and regeneration of beech forests with different game management in the Lány Game Enclosure. Forestry Journal 61: 78-88.

Andreassen K, Solberg S, Tveito OE \& Lystad SL (2006) Regional differences in climatic responses of Norway spruce (Picea abies L. Karst) growth in Norway. Forest Ecology and Management 222: 211-221.

Angelstam P \& Kuuluvainen T (2004) Boreal forest disturbance regimes, successional dynamics and landscape structures: a European perspective. Ecological Bulletins 51: 117-136.

Angermeier PL (2000) The natural imperative for biological conservation. Conservation Biology 14: 373-381.
Balcar V, Vacek S \& Henžlík V (1994) Poškození a úhyn lesních porostů v Sudetských horách: Protection of forest ecosystems, selected problems of forestry in Sudety Mts. (ed. by P Paschalis \& S Zajaczkowski) Warszawa, Biuro GEF, pp. 29-57.

Bílek L, Remeš J, Podrázský V, Rozenbergar D, Diaci J \& Zahradník D (2014) Gap regeneration in near-natural European beech forest stands in Central Bohemia - the role of heterogeneity and micro-habitat factors. Dendrobiology 71: 59-71.

Bolte A, Ammer C, Löf M, Nabuurs GJ, Schall P \& Spathelf P (2009) Adaptive forest management-a prerequisite of sustainable forestry in the face of climate change: Sustainable forest management in a changing world: a European perspective (ed. by P Spathelf) Springer, Heidelberg, pp. 115-139.

Bolte A, Hilbrig L, Grundmann B, Kampf F, Brunet J \& Roloff A (2010) Climate change impacts on stand structure and competitive interactions in a southern Swedish spruce-beech forest. European Journal Forest Research 129: 261-276.

Borůvka L, Podrázský V, Mládková L, Kuneš I \& Drábek O (2005) Some approaches to the research of forest soils affected by acidification in the Czech Republic. Soil Science and Plant Nutrition 51: 745-749.

Bréda N, Huc R, Granier A \& Dreyer E (2006) Temperate forest trees and stands under severe drought: a review of ecophysiological responses, adaptation processes and long-term consequences. Annals of Forest Science 63: 625-644.

Bridgman HA, Davies TD, Jickells T, Hůnová I, Tovey K, Bridges K \& Surapipith V (2002) Air pollution in the Krušné hory region, Czech Republic during the 1990s. Atmospheric Environment 36: 33753389.

Bulušek D, Vacek Z, Vacek S, Král J, Bílek L \& Králíček I (2016) Spatial pattern of relict beech (Fagus sylvatica L.) forests in the Sudetes of the Czech Republic and Poland. Journal of Forest Science 62: 293-305.

Buttoud G (2000) White book 2000 on mountain forest in Europe. Saint Jean d' Arvey, EOMF, Kemptville, Ontario.

Clark PJ \& Evans FC (1954) Distance to nearest neighbor as a measure of spatial relationship in populations. Ecology 35: 445-453.

Commarmot B, Bachofen H, Bundziak Y, Bürgi A, Ramp B, Shparyk Y, Sukhariuk D, Viter R \& Zingg A (2005) Structure of virgin and managed beech forests in Uholka (Ukraine) and Sihlwald (Switzerland): a comparative study. Forest Snow and Landscape Research 79: 45-56.

Commarmot B, Brändli U-B, Hamor F \& Lavnyy V (2013) Inventory of the largest virgin beech forest of Europe. A Swiss-Ukrainian scientific adventure. In Swiss Federal Institute of Forest, Snow, 
and Landscape Research, Birmensdorf. National Forestry University, Lviv, Carpathian Biosphere Reserve, Rakhiv.

Dieler J \& Pretzsch H (2013) Morphological plasticity of European beech (Fagus sylvatica L.) in pure and mixed-species stands. Forest Ecology and Management 295: 97-108.

Dobbertin M \& DeVries W (2008) Interactions between climate change and forest ecosystems: Forest ecosystems in a changing environment: identifying future monitoring and research needs (ed. by R Fischer) Report and Recommendations COST Strategic Workshop 11-13 March 2008 Istanbul, Turkey. http://www. costforest2008.org/ docs/COST-Brochure.pdf.

Ernfors M, von Arnold K, Stendahl J, Olsson M \& Klemedtsson L (2007) Nitrous oxide emissions from drained organic forest soils-an up-scaling based on C:N ratios. Biogeochemistry 84: 219-231.

Feliksik E (1995) Dendrological monitoring of the treat to the forests of Western Beskids created by industrial immission. The Beskids Bulletin 7: 23-34.

Fontes L, Bontemps J-D, Bugmann H, Van Oijen M, Garcia C, Kramer K, Linder M, Rötzer T \& Skovsgaard JP (2010) Models for supporting forest management in a changing environment. Forest Systems 19: 8-29.

Fuhrer J, Beniston M, Fischlin A, Frei Ch, Goyette S, Jasper K \& Pfister Ch (2006) Climate risks and their impact on agriculture and forests in Switzerland. Climatic Change 79: 79-102.

Füldner K (1995) Strukturbeschreibung von buchen-edellaubholz-mischwäldern. Dissertation Forstliche Fakultät Göttingen, Cuvillier Verlag, Göttingen.

Gallo J, Kuneš I, Baláš M, Nováková O \& Drury ML (2014) Occurrence of frost episodes and their dynamics in height gradient above the ground in the Jizerské hory Mts. Journal of Forest Science 60: 35-41.

Grissino-Mayer HD, Holmes RL \& Fritts HC (1992) International tree-ring data bank program library: user's manual. Tucson, Laboratory of Tree-Ring Research, University of Arizona.

Hanewinkel M \& Peyron JL (2014) Tackling climate change: The contribution of scientific knowledge in forestry. Annals of Forest Science 71: 113-115.

Hauck M, Zimmermann J, Jacob M, Dulamsuren C, Bade C, Ahrends \& B Leuschner C (2012) Rapid recovery of stem increment in Norway spruce at reduced SO 2 levels in the Harz Mountains, Germany. Environmental Pollution 164: 132-141.

Heywood VH \& Watson RT (1995) Global biodiversity assessment. Cambridge University Press, UNEP, Cambridge.
Holeksa J, Saniga M, Szwagrzyk J, Czerniak M, Staszyńska K \& Kapusta P (2009) A giant tree stand in the West Carpathians - an exception or a relic of formerly widespread mountain European forests? Forest Ecology and Management 257: 1577-1585.

Holtmeier FK (2003) Mountain timberlines: ecology, patchiness, and dynamics. Kluwer Academic Publishers, Dordrecht.

Hruška J \& Ciencala E (2003) Long-term acidification and nutrient degradation of forest soils - limiting factors of forestry today. Ministry of the Environment, Prague.

Christensen JH, Hewitson B, Busuioc A, Chen A, Gao X, Held I, Jones R, Kolli RK, Kwon WK, Laprise R, Magana R V, Mearns L, Menendez CG, Rälsänen J, Rinke A, Sarr A, Whetton P, Arritt R, Benestad R, Beniston M, Bromwich D, Caya D, Comiso J, de Elia R \& Dethloff K (2007) Regional climate projections: Climate change 2007: the physical science basis (ed. by SD Solomon, Z Chen, M Marquis, KB Averyt, M Tignor \& HL Miller) Contribution of Working Group I to the 4th assessment report of the Intergovernmental Panel on Climate Change. Cambridge University Press, Cambridge.

Christensen JH \& Christensen OB (2007) A summary of the PRUDENCE model projections of changes in European climate by the end of this century. Climatic Change 81: 7-30.

Christensen M, Hahn K, Mountford EP, Ódor P, Standovár T, Rozenbergar D, Diaci J, Wijdeven S, Mayer P, Winter S \& Vrska T (2005) Dead wood in European beech (Fagus sylvatica) forest reserves. Forest Ecology and Management 210: 267-282.

Jaehne S \& Dohrenbusch A (1997) Ein verfahren zur beurteilung der bestandesdiversität. Forstwissenschaftliches Centralblatt 116: 333-345.

Jeník J (1961) Alpinská vegetace Krkonoš, Kralického Sněžníku a Hrubého Jeseníku. Nakladatelství ČSAV, Praha.

Jönsson AM, Harding S, Bärring L \& Ravn HP (2007) Impact of climate change on the population dynamics of Ips typographus in southern Sweden. Agricultural and Forest Meteorology 146: 70-81.

Juknys R, Stravinskiene V \& Vencloviene J (2002) Tree-ring analysis for the assessment of anthropogenic changes and trends. Environmental Monitoring and Assessment 77: 1: 81-97.

Jurásek A \& Vacek S (1987) Příspěvek k problematice mrazových kýl buku lesního. Opera Corcontica 24: 133-144.

Kadlus Z (1960) K otázce námrazy v Orlických horách. 1960. Práce VÚL ČSR 18: 155 - 179.

Kadlus Z (1972) Zimní polomy 1966/67 ve vztahu k reliéfu Orlických hor. Práce VÚLHM 41: 173-197. 
Kadlus Z \& Ř́ha J (1971) Pásma zimních polomů v Orlických horách. Lesnictví 17: 735 - 750.

Kärenlampi L \& Skärby L (1996) Critical levels for ozone in Europe: testing and finalizing the concepts. University of Kuopio, Kuopio.

Korpel' S (1995) Die urwälder der Westkarparten. Gustav Fischer, Stuttgart.

Kraft G (1884) Beltrage zur lehre yon den durchforstungen, Schlagstel-lungen und lichtungshieben. Hanover, Klingworth.

Král K, Janík D, Vrška T, Adam D, Hort L, Unar P \& Šamonil P (2010) Local variability of stand structural features in beech dominated natural forests of Central Europe: implications for sampling. Forest Ecology and Managment 260: 2196-2203.

Král J, Vacek S, Vacek Z, Putalová T, Bulušek D \& Štefančík I (2015) Structure, development and health status of spruce forests affected by air pollution in the western Krkonoše Mts. in 1979-2014. Forestry Journal 61: 175-187.

Kučera T (1997) Vliv reliéfu na diverzitu vegetace. Disertační práce, PřF UK v Praze.

Leuschner C, Meier IC \& Hertel D (2006) On the niche breadth of Fagus sylvatica: soil nutrient status in 50 Central European beech stands on a broad range of bedrock types. Annals of Forest Science 63: 355-368.

Lindner M, Fitzgerald JB, Zimmermann NE, Reyer C, Delzon S, van der Maaten E, Schelhaas MJ, Lasch P, Eggers J, van der Maaten-Theunisses M, Suckow F, Psomas A, Poulter B \& Hanewinkel M (2014) Climate change and European forests: What do we know, what are the uncertainties, and what are the implications for forest management? Journal Environmental Management 146: 69-83.

Maaten-Theunissen M \& Bouriaud O (2012) Climate-growth relationships at different stem heights in silver fir and Norway spruce. Canadian Journal of Forest Research 42: 958-969.

Mäkinen H, Nöjd P, Kahle HP, Neumann U, Tveite B, Mielikäinen K, Röhle H \& Spiecker H (2002) Radial growth variation of Norway spruce (Picea abies (L.) Karst.) across latitudinal and altitudinal gradients in central and northern Europe. Forest Ecology and Management 171: 243-259.

Mareš V, Lochman V, Podrázský V \& Vacek S (1995) Changes in forest diversity under the influence of acid deposition (Orlické hory Mts. Czech republic). Caring for the forest: Research in changing World. IUFRO. World congress. 6. - 12. 4. 1995, Tampere - Finland.

Matějka K, Vacek S \& Podrázský V (2010) Development of forest soils in the Krkonoše Mts. In the period 1980 - 2009. Journal of Forest Research 56: $485-504$.

Meyer FD \& Bräker OU (2001) Climate response in dominant and suppressed spruce trees, Picea abies
(L.) Karst., on subalpine and lower montana site in Switzerland. Ecoscience 8: 105-114.

Meyer P, Tabaku V \& Lüpke BV (2003) Die struktur albanischer rotbuchen-urwälder-ableitungen für eine naturnahe buchenwirtschaft. Forstwissenschaftliches Centralblatt 122: 47-58.

Mountford MD (1961) On E. C. Pielou's index of nonrandomness. Journal of Ecology 49: 271-275.

Muzika RM, Guyette RP, Zielonka T \& Liebhold AM (2004) The influence of $\mathrm{O}_{3}, \mathrm{NO}_{2}$ and $\mathrm{SO}_{2}$ on growth of Picea abies and Fagus sylvatica in the Carpathian Mountains. Environmental Pollution 130: 65-71.

Nagel TA, Svoboda M \& Diaci J (2006) Regeneration patterns after intermediate wind disturbance in an old-growth Fagus-Abies forest in southeastern Slovenia. Forest Ecology and Management 226: 268-278.

Nagel TA, Zenner EK \& Brang P (2013) Research in old-growth forests and forest reserves: implications for integrated forestmanagement: Integrative approaches as an opportunity for the conservation of forest biodiversity (ed. by D Kraus \& F Krumm) European Forest Institute, pp. 44-50.

Näslund M (1936) Skogsförsöksanstaltens gallringsförsök i tallskog. Meddelanden från Statens Skogsförsöksanstalt 29. Stockholm, Swedish.

Neukomm R, Gergis J, Karoly DJ, Wanner H, Curran M, Elbert J, González-Rouco F, Linsley BK, Moy AD, Mundo I, Raible CC, Steig EJ, van Ommen T, Vance T, Villalba R, Zinke J \& Frank D (2014) Inter-hemispheric temperature variability over the past millennium. Nature Climate Change 4: 362-367.

Oheimb G, Westphal C, Tempel H \& Härdtle W (2005) Structural pattern of a near-natural beech (Fagus sylvatica) forest (Serrahn, North-east Germany). Forest Ecology and Management 212: 253-263.

Okland T, Rydgren K, Okland RH, Storaunet KO \& Rolstad J (2003) Variation in environmental conditions, understorey species number, abundance and composition among natural and managed $\mathrm{Pi}$ cea abies forest stands. Forest Ecology and Management 177: 17-37.

Orwig DA \& Abrams MD (1997) Variation in radial growth responses to drought among species, site, and canopy strata. Trees 11: 474-484.

Parviainen J, Bozzano M, Estreguil C, Koskela J, Lier M, Vogt P \& Ostapowicz K (2007) Maintenance, conservation and appropriate enhancement of biological diversity in forest ecosystems: State of Europe's Forests 2007 - the MCPFE report on sustainable forest management in Europe. Ministerial Conference on the Protection of Forests in Europe (ed. by M Köhl \& E Rametsteiner) Liaison Unit, Warsaw, pp. 45-72. 
Parviainen J, Bucking W, Vandekerkhove K, Schuck A \& Paivinen R (2000) Strict forest reserves in Europe: efforts to enhance biodiversity and research on forests left for free development in Europe (EU-COST-Action E4). Forestry 73: 107-118.

Petráš R \& Pajtík J (1991) Sústava česko-slovenských objemových tabuliek drevín. Lesnícky časopis 37: 49-56.

Pichler P \& Oberhuber W (2007) Radial growth response of coniferous forest trees in an inner Alpine environment to the heat-wave in 2003. Forest Ecology and Management 242: 688-699.

Podrázský V \& Vacek S (1996) Dynamika poškození smrkových a bukových porostů v CHKO Orlické hory. IV. Stav půd v přírodních rezervacích. Příroda 5: 123-136.

Pretzsch H (2006) Wissen nutzbar machen für das Management von Waldökosystemen. Allgemeine Forstzeitschrift/Der Wald 61: 1158-1159.

Pretzsch H, Block J, Dieler J, Dong PH, Kohnle U, Nagel J, Spellmann H \& Zingg A (2010) Comparison between the productivity of pure and mixed stands of Norway spruce and European beech along an ecological gradient. Annals of Forest Science 67: 712.

Pretzsch H \& Schütze G (2014) Size-structure dynamics of mixed versus pure forest stands. Forest Systems 23: 560-572.

Reineke LH (1933) Perfecting a stand density index for even-aged forests. Journal of Agricultural Research 46: 7: 627-638.

Ripley BD (1981) Spatial statistics. 1st ed. John Wiley \& Sons, New York.

Rohner B, Weber P \& Thürig E (2016) Bridging tree rings and forest inventories: How climate effects on spruce and beech growth aggregate over time. Forest Ecology and Management 360: 159-169.

Rugani T, Diaci J \& Hladnik D (2013) Gap dynamics and structure of two old-growth beech forest remnants in Slovenia. PloS one 8: e52641.

Rybníček M, Žid T \& Kolář T (2010) Radial growth and health condition of Norway spruce (Picea abies (L.) Karst.) stands in relation to climate (Silesian Beskids, Czech Republic). Geochronometria 36: 9-16.

Scherer-Lorenzen M, Körner C \& Schulze ED (2005) Forest diversity and function: temperate and boreal systems. Springer-Verlag, Berlin Heidelberg.

Schlyter P, Stjernquist I, Bärring L, Jönsson AM \& Nilsson C (2006) Assessment of the impacts of climate change and weather extremes on boreal forests in northern Europe, focusing on Norway spruce. Climate Research 31: 75-84.

Schmid I \& Kazda M (2001) Vertical and radial growth of coarse roots in pure and mixed stands of Fagus sylvatica and Picea abies. Canadian Journal of Forest Research 31: 539-548.
Schweingruber FH, Eckstein D, Serre-Bachet F \& Bräker OU (1990) Identification, presentation and interpretation of event years and pointer years in dendrochronology. Dendrochronologia 8: 9-38.

Siitonen J (2001) Forest management, coarse woody debris and saproxylic organisms: Fennoscandian boreal forests as an example. Ecological Bulletins 49: 11-41.

Slodičák M \& Novák J (2006) Silvicultural measures to increase the mechanical stability of pure secondary Norway spruce stands before conversion. Forest Ecology and Management 224: 252-257.

Spetich AM, Liechty HO, Stanturf JA, Marion DA, Luckow K, Meier CE \& Guldin JM (2002) Coarse woody debris of a prerestoration shortleaf pinebluestem forest: Proceedings of the eleventh biennial southern silvicultural research conference (ed. by KW Outcalt) General Technical Report. SRS-48. Asheville, NC: U.S. Department of Agriculture, Forest Service, Southern Research Station.

Spiecker H (1999) Overview of recent growth trends in European forests. Water Air and Soil Pollution 116: 33-46.

Stoyan D \& Stoyan H (1992) Fraktale formen und punktfelder: methoden der geometrie-statistik. Akademie verlag $\mathrm{GmbH}$, Berlin.

Šmelko Š, Šebeň V, Bošela M, Merganič J \& Jankovič J (2008) Národná inventarizácia a monitoring lesov SR 2005 - 2006. NLC, Zvolen.

Špulák O \& Souček J (2010) The Sibyla model and development of beech forests affected by air pollution. Central European Journal of Biology 5: 371-383.

Štefančík I \& Bošela M (2014) An influence of different thinning methods on qualitative wood production of European beech (Fagus sylvatica L.) on two eutrophic sites in the Western Carpathians. Journal of Forest Science 60: 406-416.

Štefančík I (2015) Growth, structure and production of beech stands with different thinning regimes. The National Forest Centre, Zvolen.

Tranquillini W (1979) Physiological Ecology of the Alpine Timberline: Tree existence at high altitudes with special reference to the European Alps. Ecological Studies 31. Springer, Berlin, Heidelberg, New York.

Vacek S, Podrázský V \& Mareš V (1994) Dynamika poškození smrkových a bukových porostů $\mathrm{v}$ CHKO Orlické hory. I. Změny ve stromovém patře. Př́roda 1: 153-164.

Vacek S (2003) Mountain forests of the Czech Republic. Ministry of agriculture of the Czech Republic, Prague.

Vacek S \& Hejcman M (2012) Natural layering, foliation, fertility and plant species composition of a Fagus sylvatica stand above the alpine timberline in 
the Giant (Krkonoše) Mts., Czech Republic. European Journal of Forest Research 131: 799-810.

Vacek S, Moucha P, Bílek L, Mikeska M, Remeš J, Simon J, Hynek V, Šrůtka P, Schwarz O, Mánek J, Baláš M, Dort M, Podrázskỳ V, Hejcman M, Hejcmanová $P$, Málková J, Stonawski J, Bednařík J, Vacek Z, Malík K, Štícha V \& Bulušek D (2012) Péče o lesní ekosystémy $\mathrm{v}$ chráněných územích ČR. Ministerstvo životního prostředí, Praha.

Vacek S, Hůnová I, Vacek Z, Hejcmanová P, Podrázský V, Král J, Putalová T \& Moser WK (2015a) Effects of air pollution and climatic factors on Norway spruce forests in the Orlické hory Mts. (Czech Republic), 1979-2014. European Journal of Forest Research 134: 1127-1142.

Vacek Z, Vacek S, Bílek L, Král J, Remeš J, Bulušek D \& Králičček I (2014) Ungulate impact on natural regeneration in spruce-beech-fir stands in Černý důl Nature Reserve in the Orlické Hory Mountains, case study from Central Sudetes. Forests 5: 2929-2946.

Vacek Z, Vacek S, Bílek L, Remeš J \& Štefančík I (2015b) Changes in horizontal structure of natural beech forests on an altitudinal gradient in the Sudetes. Dendrobiology 73: 33-45.

Vanbergen AJ, Woodcock BA, Watt AD \& Niemelä J (2005) Effect of land-use heterogeneity on carabid communities at the landscape scale. Ecography 28: 3-16. von Lüpke B, Ammer C, Bruciamacchie $M$, Brunner A, Ceitel J, Collet C, Deuleuze Ch, Diplacido J, Huss J, Jankoviè J, Kantor P, Bo Larsen J, Lexer M, Löf M, Longauer R, Madsen P, Modrzyñski J, Mosandl R, Pampe A, Pommerening A, Štefančik I, Tesař V, Thompson R \& Zientarski J (2004) Silvicultural strategies for conversion: Norway spruce conversion: options and consequences (ed. by H Spiecker, E Klima, JP Skovsgaard, H Sterba \& von K Teuffel) European Forest Institute Research Reports 18, pp. 121-164.

von Oheimb G, Westphal C, Tempel H \& Härdtle W (2005) Structural pattern of a near-natural beech (Fagus sylvatica) forest (Serrahn, North-east Germany). Forest Ecology and Management 212: 253-263.

Webster CR \& Lorimer CG (2003) Comparative growing space efficiency of four tree species in mixed conifer-hardwood forests. Forest Ecology and Management 177: 361-377.

Wesolowski T (2005) Virtual conservation: How the European Union is turning a blind eye to its vanishing primeval forests. Conservation Biology 19: 1349-1358.

Yamaguchi DK (1991) A simple method for cross-dating increment cores from living trees. Canadian Journal of Forest Research 21: 414-416.

Yamamoto SI (2000) Forest gap dynamics and tree regeneration. Journal of Forest Research 5: 223229. 